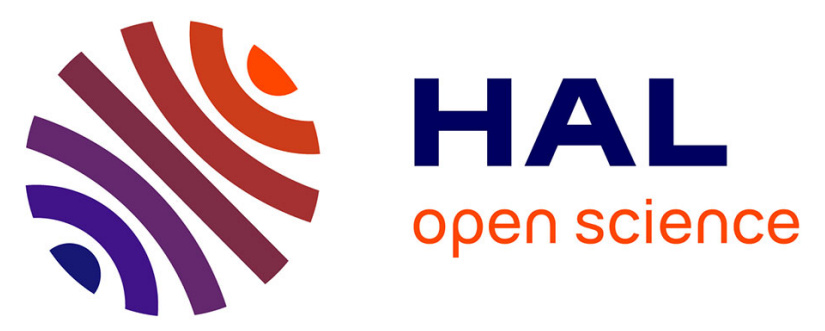

\title{
Neoproterozoic crustal evolution in Southern Chad: Pan-African ocean basin closing, arc accretion and late- to post-orogenic granitic intrusion.
}

André Pouclet, Max Vidal, J.C. Doumnang, Jean-Paul Vicat, Rigobert

Tchameni

\section{To cite this version:}

André Pouclet, Max Vidal, J.C. Doumnang, Jean-Paul Vicat, Rigobert Tchameni. Neoproterozoic crustal evolution in Southern Chad: Pan-African ocean basin closing, arc accretion and lateto post-orogenic granitic intrusion.. Journal of African Earth Sciences, 2006, 44, pp.543-560. 10.1016/j.jafrearsci.2005.11.019 . hal-00073651

\section{HAL Id: hal-00073651 \\ https://hal-insu.archives-ouvertes.fr/hal-00073651}

Submitted on 30 May 2006

HAL is a multi-disciplinary open access archive for the deposit and dissemination of scientific research documents, whether they are published or not. The documents may come from teaching and research institutions in France or abroad, or from public or private research centers.
L'archive ouverte pluridisciplinaire HAL, est destinée au dépôt et à la diffusion de documents scientifiques de niveau recherche, publiés ou non, émanant des établissements d'enseignement et de recherche français ou étrangers, des laboratoires publics ou privés. 


\title{
Neoproterozoic crustal evolution in Southern Chad: Pan- African ocean basin closing, arc accretion and late- to post-orogenic granitic intrusion
}

\author{
A. Pouclet ${ }^{\mathrm{a},}$ M. Vidal ${ }^{\mathrm{a}}$, J.-C. Doumnang ${ }^{\underline{b}}$, J.-P. Vicat $^{\mathrm{a}}$ and R. Tchameni $^{\mathrm{c}}$ \\ ${ }^{a}$ Institut des Sciences de la Terre d'Orléans, UMR 6113, Université, B.P. 6759, 45067 \\ Orléans Cedex 2, France \\ ${ }^{b}$ Laboratoire de Géologie, Faculté des Sciences, Université, B.P. 1027, N’Djamena, Tchad \\ ${ }^{c}$ Département des Sciences de la Terre, Faculté des Sciences, Université, B.P. 454, \\ Ngaoundéré, Cameroun
}

Keywords: Pan-African orogen; Volcanic arc; Post-orogenic granites; Neoproterozoic; Chad

\begin{abstract}
In the Lake Léré region, southern Chad, Neoproterozoic terrains are distributed in four lithostructural groups that reveal the geotectonic evolution of a part of the Pan-African orogenic domain. The first group includes basaltic volcanic rocks and fine-grained detrital sedimentary rocks of pre-tectonic basins that were emplaced in an extensional regime, close to a volcanic arc. The second and third groups include calc-alkaline gabbroic intrusions emplaced at an upper crustal level and a midcrustal tonalite, respectively, that are interpreted to be the roots of an active margin volcanic arc. These first three groups experienced WNW to ESE compression, and may belong to a fore-arc basic - volcanic arc-back-arc basin system that was accreted eastward to the Palaeoproterozoic Adamaoua-Yadé Block. The fourth group includes post-tectonic granite plutons invading the older groups. This paper documents the accretion processes in the southern margin of the Saharan Metacraton.
\end{abstract}

\section{Geologic background}

The area south of Chad exposes Neoproterozoic basement rocks cut by large WNW-ESE orientated Cretaceous grabens. The basement consists of epi to mesozonal metamorphic belts trending SSW-NNE and granitic batholiths. The grabens are filled by lacustrine and marine sediments. Important fracture systems, striking $\mathrm{N} 0^{\circ}, \mathrm{N} 40^{\circ}$ and $\mathrm{N} 100^{\circ}$, have been exploited by Jurassic to Cretaceous dolerite dykes.

The basement rocks belong to the large Pan-African mobile belt which extends from central to middle-western Africa, between Archean to Palaeoproterozoic cratons: the Congo and M'Bomu cratons to the south and the south-east, the Saharan-Nilotic cratons to the north-east, north and north-west, the Touareg craton to the west-north-west, and the West-African craton to the west (Fig. 1). In the Pan-African domain, two main mobile belts are distinguished: the Dahomeyides to the west, that were thrust westward onto the West-African craton, and the Oubanguides to the south, that were thrust southward onto the Congo and M'Bomu cratons. South-Chad is located in an intermediate position within this complex orogenic system. Until now, the geology of South-Chad was poorly known (Schneider and Wolff, 1992, Kasser, 
1995, Kusnir, 1995 and Kusnir and Moutaye, 1997). Our investigations focus on the southernmost part of Chad, at the Cameroon border, in the Mayo Kebbi Province, around the Lake Léré (Fig. 2). This area is located on the northern side of the Oubanguides belt that extends into Central Cameroon and the north of the Central Africa Republic. We chose this area to determine (1) if it belongs to the internal zone of the belt or to another zone, or (2) if it is an exotic terrain accreted to the Ouganguides belt. We also hope to determine its place in the overall Pan-African domain.

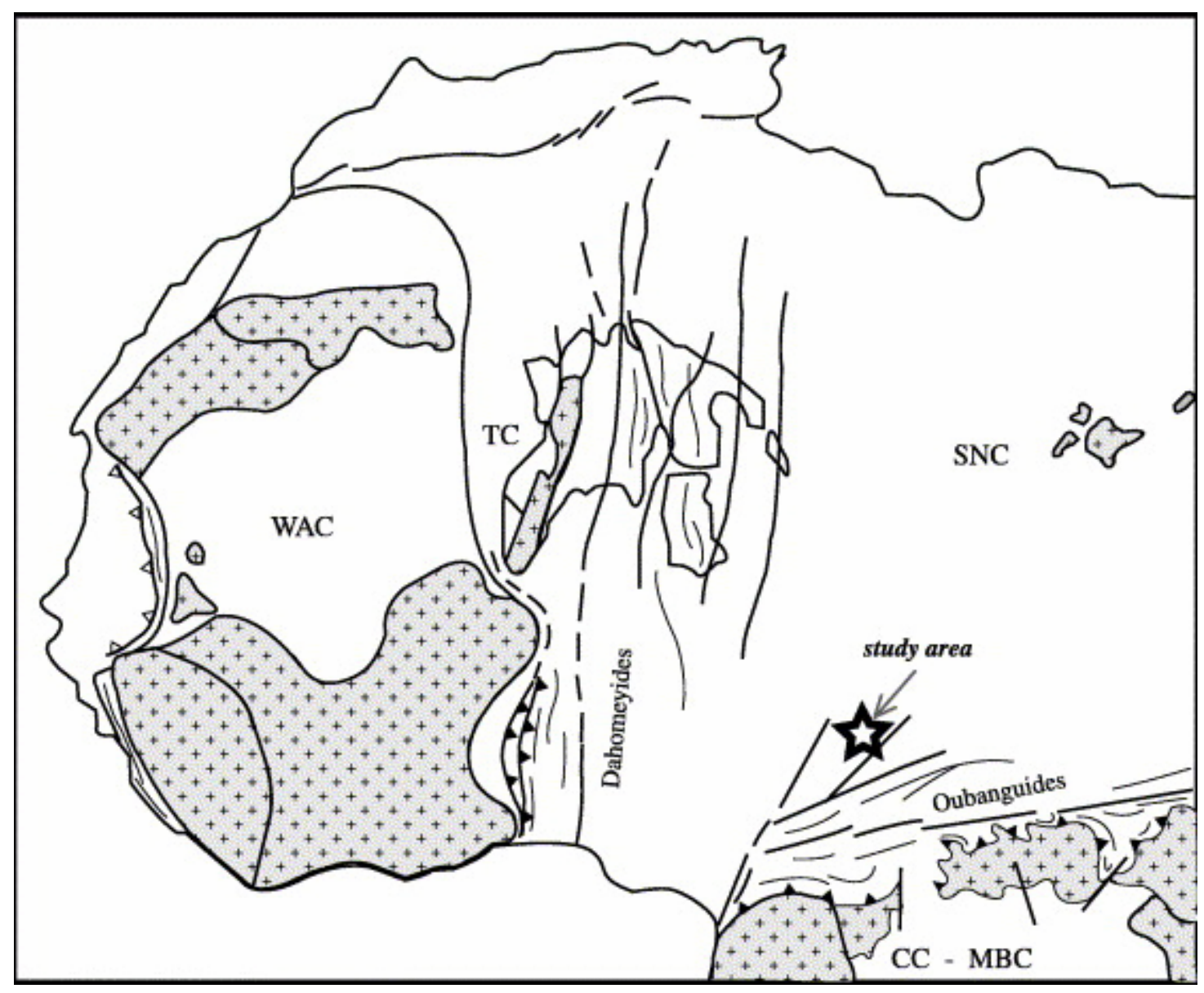

Fig. 1. Location of the study area in the Oubanguides belt. CC, Congo Craton; MBC, M'Bomu Craton; SNC, Saharo-Nilotic Craton; TC, Touareg Craton; WAC, West Africa Craton. 


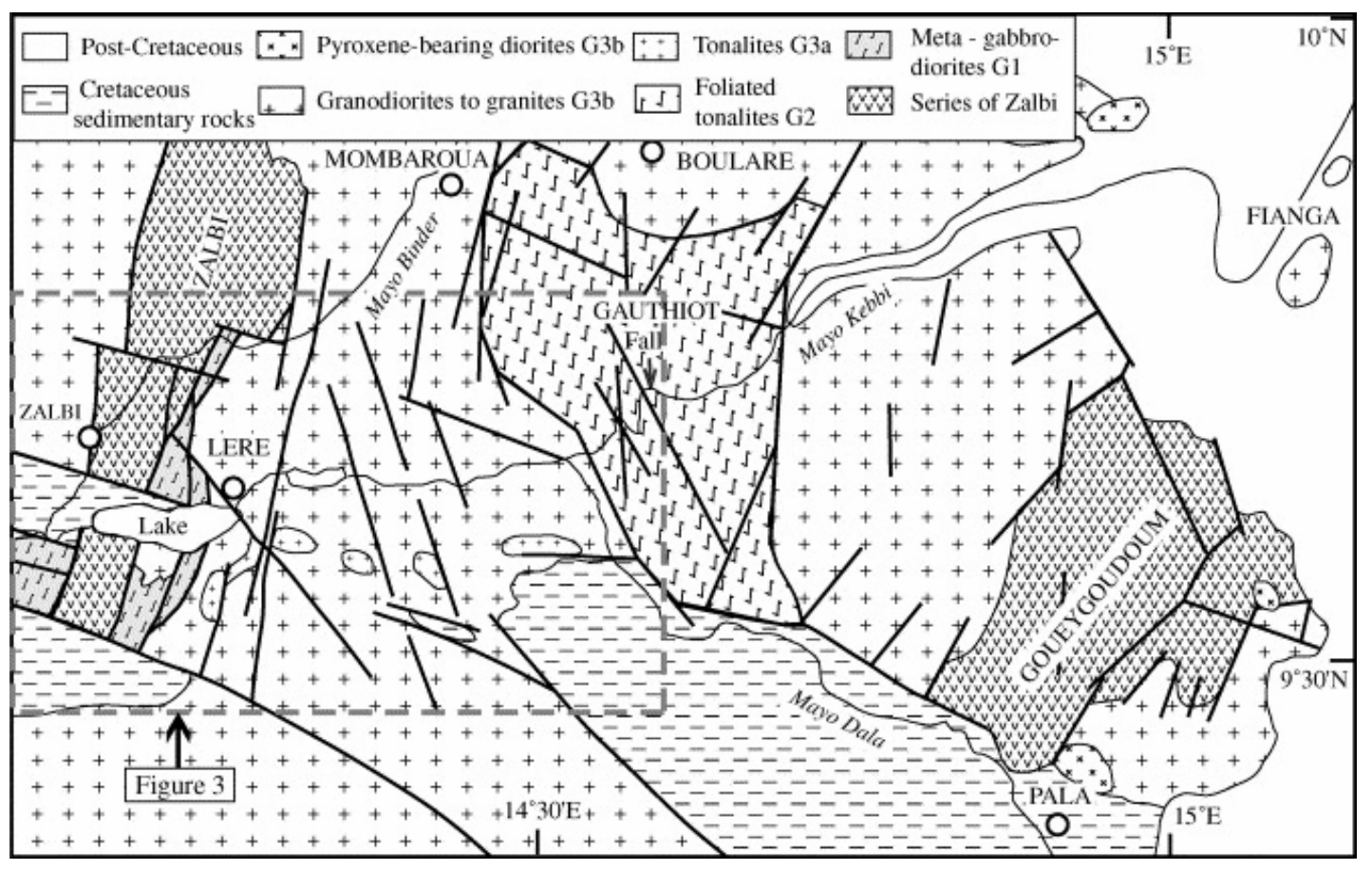

Fig. 2. Geological map of the Léré-Pala region.

\section{Structural and lithological formations}

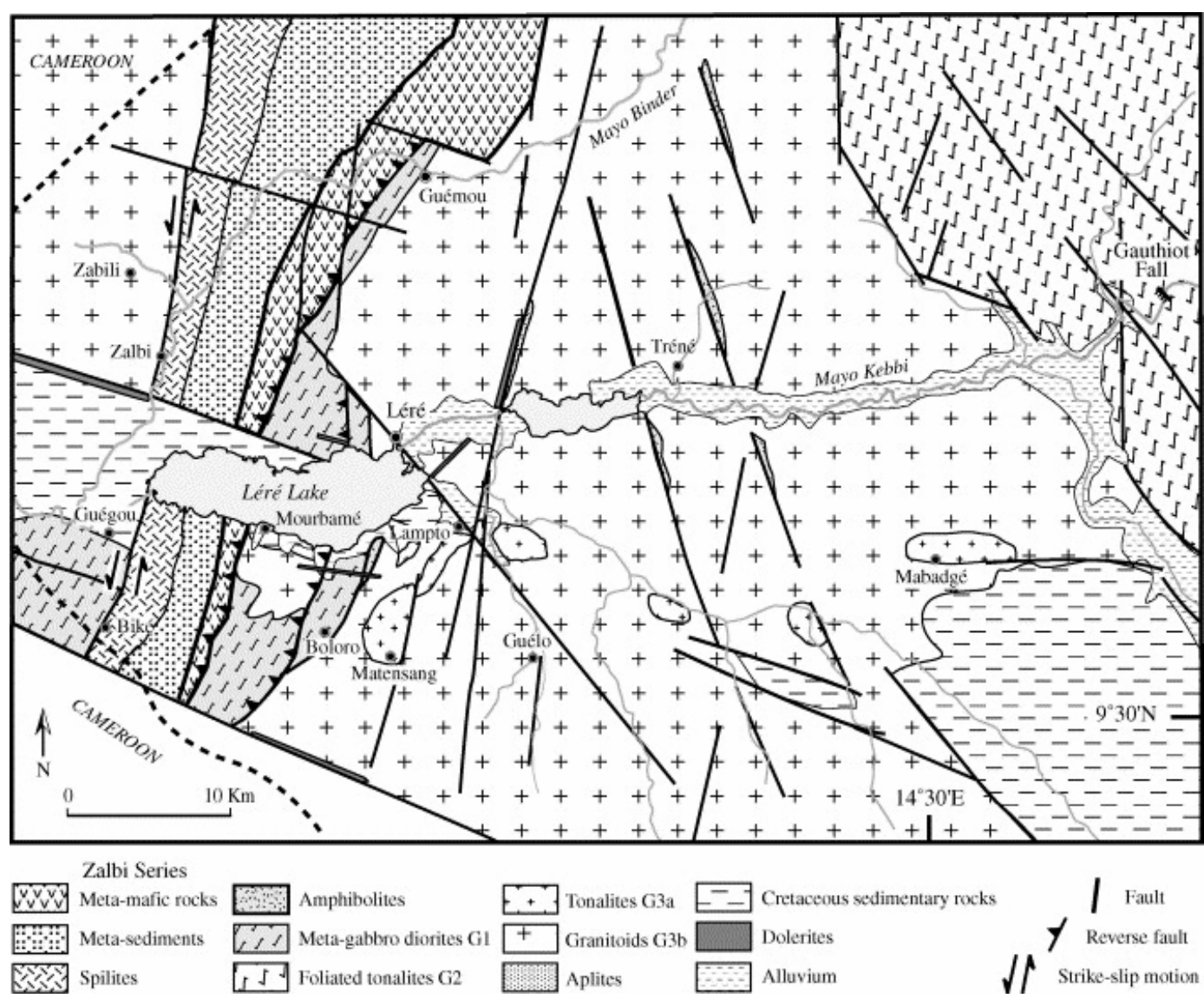

Fig. 3. Detailed geological map of the Lake Léré area. 
Structural and petrological studies led us to distinguish four Precambrian formations within the Mayo Kebbi area, one volcano-sedimentary formations and three plutonic groups, in the following chronological order: (1) the Volcanic and Sedimentary Group of Zalbi (VSZ), (2) the first intrusion phase of gabbros-diorites, 3) the second intrusion phase of tonalitic rocks, and (4) the third intrusive phase of batholithic dioritic to granitic plutons (Fig. 2, Fig. 3, Fig. 4, Fig. 5 and Fig. 6 ).

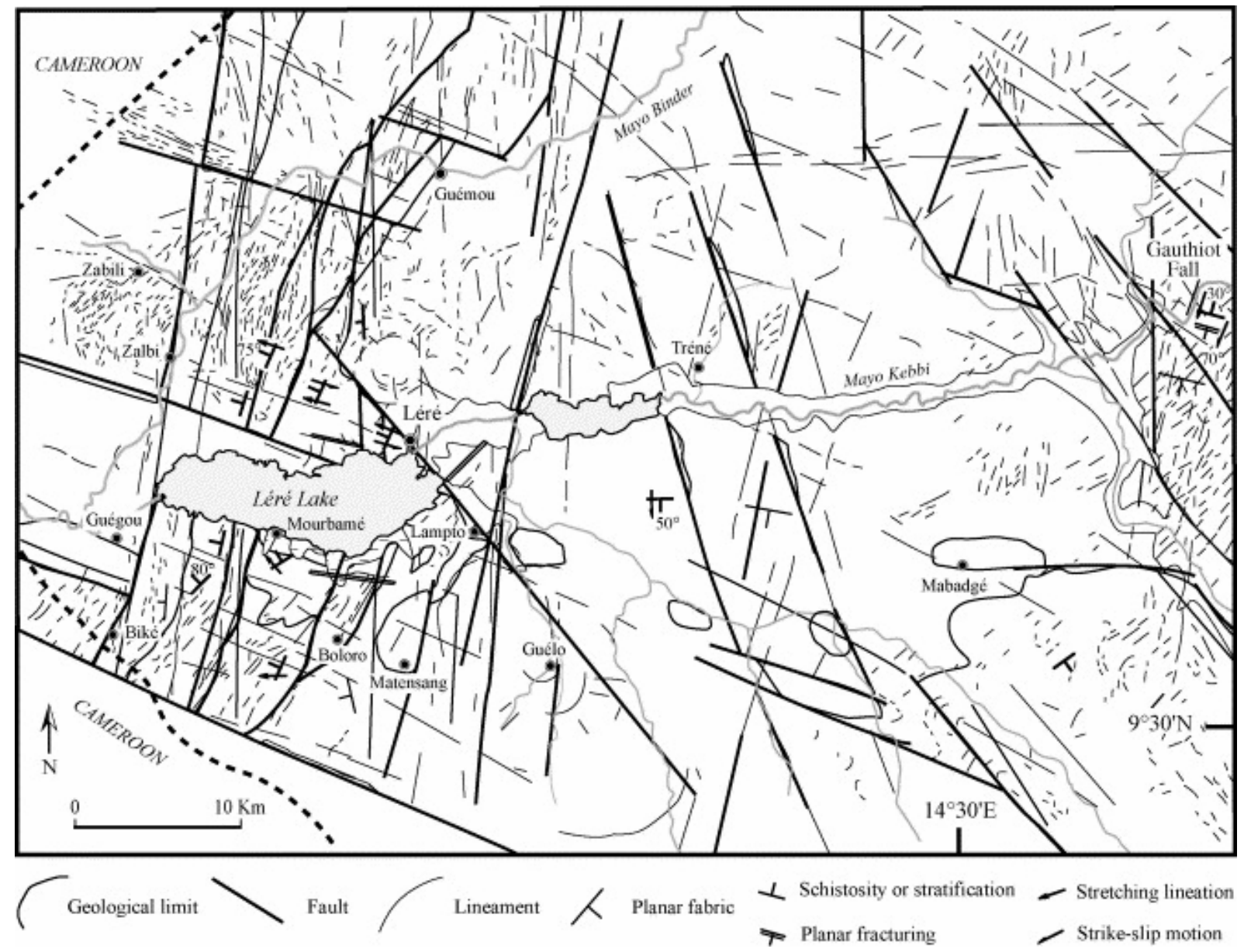

Fig. 4. Structural map of the Lake Léré area. Outline of lineaments using spot image. Note the fine and dense linear patterns of the folded or foliated rock groups: Zalbi Group, igneous rocks G1 and G2. In contrast, the posttectonic G3 rocks show large and sub-circular patterns. The late brittle tectonic is expressed by a few but long lineaments striking NNE, NNW, NW and WNW, the latter being exploited by dolerite dykes and Mesozoic graben faulting. 


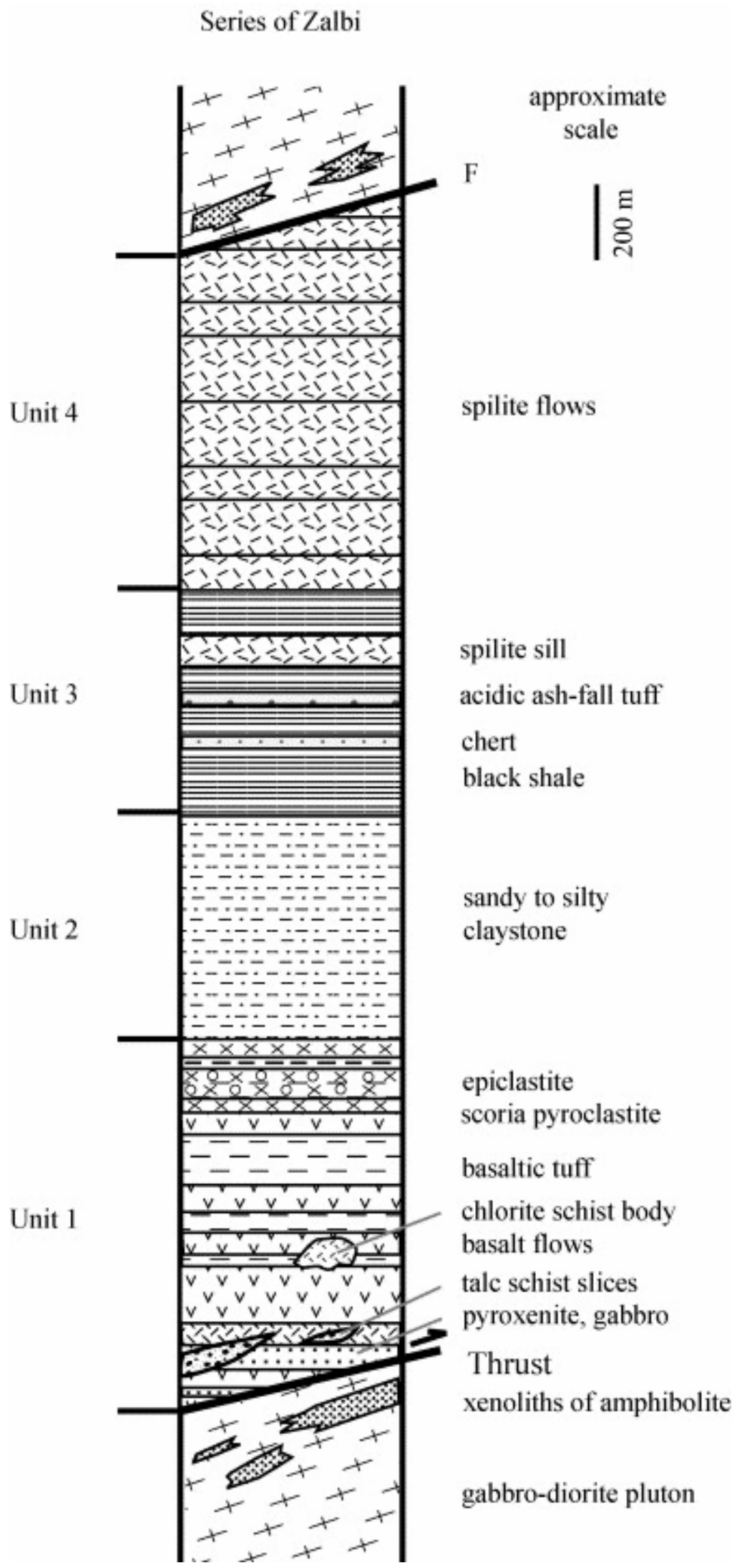

Fig. 5. Stratigraphic column of the Zalbi Group. The base is thrust on the G1 gabbro-dioritic bodies. The upper part is limited by the intrusions of the Guégou diorite and of the Zabili granite. The xenoliths of amphibolite resulted from the thermal metamorphism of mafic material of the Zalbi Group by pre- to post-tectonic intrusions. 


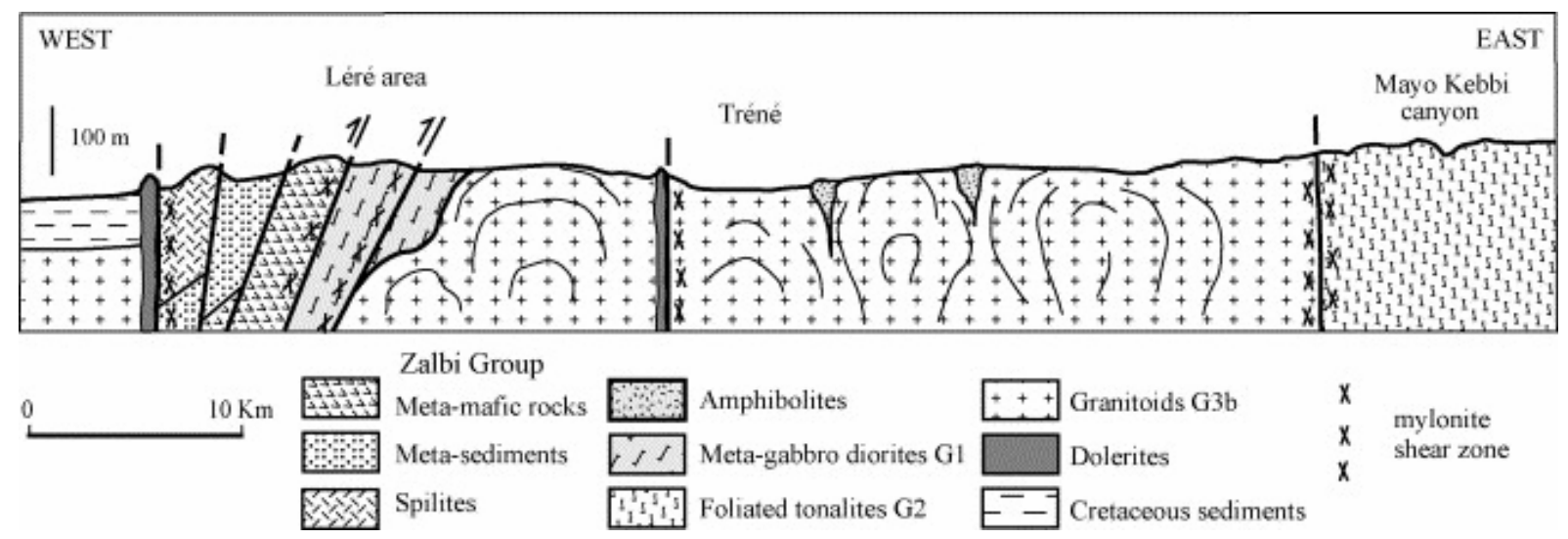

Fig. 6. W-E cross-section from NW of the Lake Léré to the Gauthiot Fall massif.

\subsection{The volcanic and sedimentary group of Zalbi (VSZ)}

The VSZ Group crops out in two basins, the Goueygoudoum basin to the east, and the Zalbi basin to the west, at the Cameroon border (Fig. 2). The Goueygoudoum area is a covered by thick soil and shows only few bedrock outcrops. The Zalbi area has good outcrops around Lake Léré and along the Mayo Binder valley, allowing construction of a complete lithostratigraphic column. The Zalbi basin is a faulted SSW-NNE trending elongated trough bounded to the west by left-lateral strike-slip faults and to the east by a $70^{\circ}$ westward dipping reverse fault (Fig. 3 and Fig. 4). It is crosscut by WNW-ESE faults that control the development of the Cretaceous basins. It includes epimetamorphic volcanic and sedimentary formations. A WNW-ESE compressional event resulted in isoclinal folding and development of schistosity. Fold axes are striking $\mathrm{N} 30^{\circ}$ with axial planes dipping $70^{\circ}$ to the west.

Four units are distinguished in the VSZ of the Zalbi basin, from base to top: Unit 1, basaltic volcanic and volcano-sedimentary rocks, Unit 2, sandy and silty claystones, Unit 3, black shales, and Unit 4, spilitic rocks. The lower part of Unit 1 and the upper part of Unit 4 record the thermal metamorphic effects of the neighbouring plutons. Away from these plutons and from the volcanic flows, the middle Units 2 and 3 are only weakly metamorphosed in the upper epizone.

The lower part of Unit 1 consists of metabasites interbedded with chlorite schists, interpreted as subaqueous basaltic flows with intercalated volcano-sedimentary rocks. Some massive strata (thick flows and sills) in this sequence are determined as meta-gabbros and metapyroxenites. In the basal part of the pile, a few decametre-scale lenticular layers of talc schists and grey chlorite schists were observed. Their mineral composition (saponite, talc, Cr-rich magnetite and chromite) indicates that they are meta-ultrabasites. Stratigraphically higher, dispersed metre-scale bodies of sulphur-rich green chorite and silexite aggregates are intercalated with the meta-basalts. They are interpreted to be hydrothermally altered basaltic rocks. In the middle part of the unit, the metabasite strata are more heterogeneous in thickness and grain size and include basaltic pyroclastic flows and beds. The middle to the upper part of Unit 1 is characterized by an increasing amount of sedimentary material, and consists of metaepiclastites, quartz-rich sericite schists and silty-claystones. 
Unit 2 is a thick and monotonous pile of sandy to silty claystones. It shows a succession of decimetre-scale fining-upward sequences. The fine-grained detrital material was supplied from a distal terrigenous source.

Unit 3 is dominated by deposition of black shales, suggesting deepening of the basin. The prevalent rock is a pyrite-rich ampelite. From the middle to the upper part, a number of decimetre-scale grey cherts and acidic ash-fall layers are interbedded. The upper part is characterized by intercalation of metre-scale sills of spilite.

Unit 4 is a stack of spilitic flows of variable thickness.

\subsection{The first plutonic Group (G1)}

The G1 Group is characterized by compressional deformation and shearing. It consists of protomylonitic to mylonitic kilometre-scale intrusions of gabbroic to dioritic rocks located at the borders of the Zalbi Basin (Fig. 3 and Fig. 4). These include the Mourbamé, Boloro and Guémou gabbros, to the east, and the Guégou diorite, to the west. These bodies experienced the eastward thrusting of the Zalbi Basin, and also were involved in the same WNW-ESE compression event. They gained a pervasive planar fabric and solid-state deformation that developed a proto-mylonitic texture. Intercalations of foliated amphibolites are disposed along the tectonic contacts, at the edges with the Zalbi basin and at the faulted zone bordering the late and undeformed granite plutons. A schematic cross-section illustrates the tectonic setting (Fig. 6).

The Mourbamé and Boloro blocks are separated by reverse faults. A large apophysis of pegmatitic granite intrudes the Mourbamé block. The Guémou block is overthrust by the Zalbi formations at its western side. It is invaded by a late granite intrusion at its eastern side. In this latter area, typical magmatic stoping processes are well developed, with disintegration of the gabbro by the granite mass, mechanical mixing and sinking of large blocks of gabbro, and also of foliated metabasites from the Zalbi formations, into the pegmatitic roof of the granite pluton. To the west, the dioritic body of Guégou caused a strong thermal metamorphism in the spilites of the upper Zalbi Group.

\subsection{The second plutonic Group (G2)}

The G2 Group includes tonalitic plutons intruded farther east in the Léré area. They constitute the massif of the Gauthiot Fall and are bounded to the west by $\mathrm{N} 110^{\circ}$ and $\mathrm{N} 150^{\circ}$ faults that were rejuvenated during the Cainozoic tectonic events, and to the east and north-east, by the late granite plutons (Fig. 2 and Fig. 3). The massif is cut by a pervasive solid-state to ductile deformation characterized by a sub-vertical foliation, gneissic layering trending $\mathrm{N} 30^{\circ}$, and a horizontal mineral lineation. Foliation and layering involving complete and pressure guided recrystallization were generated at a mesocrustal level. In that condition, the vertical lithostatic pressure exceeds the horizontal stress effect and the strain X-axis becomes horizontal, that causes the horizontal lineation. Then, the structural features are interpreted to be the result of a WNW-ESE compressive stress at moderate to high pressure. In the Gauthiot Fall area, a second and lower pressure stress event is recorded by a $\mathrm{N} 110^{\circ}$ striking schistosity dipping $10^{\circ}$ to the north, and a set of mylonitized shear planes, with the same $\mathrm{N} 110^{\circ}$ strike but dipping $70^{\circ}$ to the south (Fig. 4). The mylonites have a down dip $\mathrm{N} 210^{\circ}$ stretching lineation that indicates SSW transport. This second stress occurred after the uprising of the Gauthiot Fall massif. 


\subsection{The third plutonic Group (G3)}

The G3 Group includes post-tectonic plutons that form the Pala-Léré batholith (Fig. 2). In the Léré area, two successive magmatic pulses are distinguished (Fig. 3). The first intrusive bodies (G3a) are mainly tonalitic to trondhjemitic and crop out east and south of Léré at Matansang, Lampto and Mabadgé. They are devoid of any pervasive deformation. They may represent the remains of a large pluton that was subsequently engulfed by large granite plutons of the second magmatic pulse (G3b). These plutons coalesced to create batholith domains, north of Pala, east of Léré, and west of Zalbi. Most of these plutons, of decakilometric size, are sub-circular and equigranular. East of Léré, three medium-sized plutons of monzogranite and biotite granite are exposed: the Léré, Tréné and Guélo plutons. Each pluton is characterized by a sub-circular planar fabric that is sub-horizontal in the middle and steeply dipping toward the edges (Fig. 4 and Fig. 6). Distribution of the thermally metamorphosed and deformed xenoliths of the former country rocks (mainly amphibolites and amphibole-bearing gneiss) is parallel to this fabric. The pegmatitic dome-shaped roof of the plutons is commonly observed. In this roof zone, xenoliths are moderately deformed and metamorphosed. Some large sub-horizontal panels consist of metabasites, metagabbros and chlorite schists, particularly in the Léré and Tréné area. These rocks share the same composition as those of the Unit 1 of the Zalbi Group. Between the plutons, and along the sub-meridianal fracture zones, large inter-pluton screens are foliated and thermally transformed into meta-gabbro, amphibolite, amphibole-bearing gneiss and gneiss. In a few zones, screens of amphibolite-gneiss reach a kilometre scale. These screens also derived from the former country rocks that have been invaded by the igneous intrusions.

To the west of the Zalbi basin, the biotite granite pluton of Zabili exhibits the same lithostructural features, with a thick pegmatitic cap. To the northeast, the muscovite-bearing granite or leucogranite of Boularé intruded the Gauthiot Fall tonalite (Fig. 2). Farther to the east, granodiorite and granite bodies in the Pala area and a sub-circular biotite granite pluton near Fianga belong to the same plutonic phase. A single intrusion of pyroxene-bearing quartz diorite crops out north of Pala, and is also related to this phase.

\section{Petrochemical compositions}

Samples of the four lithostructural groups have been analysed, for their mineral compositions by electron microprobe analysis at the joint microprobe laboratory of Centre National pour la Recherche Scientifique-University-Bureau de Recherches Géologiques et Minières of Orléans, and for their geochemical compositions, by inductively-coupled plasma emission spectrometry (major elements) and inductively-coupled plasma-mass spectrometry (minor and trace elements) at the analytical lab of the Centre de Recherches Pétrographiques et Géochimiques of Nancy.

\subsection{The Zalbi group magmatic rocks}

\subsubsection{Petrography}

Petrological investigations are focused on the magmatic rocks including basalts, spilites, gabbros, pyroxenites, and ultrabasites. In spite of the epizonal metamorphism and local development of foliation, magmatic textures are recognizable except near shear zones and pluton contacts, and in some highly hydrothermally altered areas. The primitive magmatic 
minerals are mostly badly preserved. They are replaced by geenschist minerals, either by static or by dynamic foliation-guided recrystallization. Spilitization of lavas of the upper Unit has modified the magmatic assemblage into recrystallized spilitic secondary minerals.

The basalts have a microlitic porphyritic texture, with variable amounts of phenocrysts. Phenocryst phases include albitized plagioclase and clinopyroxene recognizable by shape but now occurring as pseudomorphic Mg-hornblende. The groundmass includes microlites of albitized plagioclase, microcrysts of epidote rich in clinozoïsite (Cz\% 75.6-76.1) and microcrysts of magnetite, in a random aggregate of chlorite (ripidolite-picnochlorite), actinolite and calcite. The gabbros preserve a granular texture and magmatic phases comprising plagioclase, clinopyroxene and rare magnetite. Local cumulate layers are observed. The calcic cores of large plagioclase reach An55. These minerals are partly replaced by associated albite and epidote. The relict cores of the pyroxene crystals have a composition of diopside (Mg\% 40.7-43.5, Fe\% 8.0-11.6, Ca\% 46.0-49.3) and are very poor in $\mathrm{Ti}, \mathrm{Al}$ and $\mathrm{Na}$. The rest of the ferro-magnesian minerals are replaced by calcic amphibole ranging from Mg-hastingsite to tchermakitic hornblende and Mg-hornblende. A late magmatic formation for some of these amphiboles cannot be excluded. The groundmass includes actinolite, epidote, chlorite (ripidolite), albite, quartz and calcite. The pyroxenites are characterized by cumulate textures and a high amount of former pyroxenes. These pyroxenes were magmatic clinopyroxene, and perhaps orthopyroxene, replaced by Mg-hornblende, actinolite, tremolite, and cummingtonite. The abundant flakes of secondary chlorite are Mgrich clinochlore.

The talc-rich lenticular bodies sampled close to the base of the lower Unit are former ultrabasic rocks with no original texture visible. The mineral content is dominated by talc and saponite. Sparse Cr-rich magnetite $\left(4.2<\mathrm{Cr}_{2} \mathrm{O}_{3} \%<7.9\right.$; chromite $\left.\%=5.7-12.0\right)$ and $\mathrm{Fe}-$ chromite $\left(\mathrm{Cr}_{2} \mathrm{O}_{3} \%=33.0\right.$; chromite $\left.\%=51\right)$ are present. These $\mathrm{Cr}$-minerals are devoid of $\mathrm{Al}$, $\mathrm{Mg}$ and $\mathrm{Ti}$, and are of secondary origin. The other phases include Mg-carbonate (magnesite 90.3-91.5\%; siderite 7.8-9.3\%), titanite, rutile and pyrrhotite. The talc schists are associated with chlorite schists made of aggregated ripidolite-pycnochlorite, paragonite and muscovite, and of $\mathrm{Mg}-\mathrm{Fe}-\mathrm{Ca}$ carbonates (dolomite 42.1-57.4\%, siderite 19.0-28.7\%, calcite 22.528.9\%), epidote, albite, magnetite $\left(0<\mathrm{TiO}_{2} \%<2.6\right)$, rutile, and pyrrhotite. These latter chlorite-rich units, and other isolated oval-shaped bodies of similar composition, may have originated from intrabasinal hydrothermal alteration.

\subsubsection{Geochemistry}

Chemical analyses of the Zalbi Group magmatic rocks are given in Table 1. Chemical compositions of these rocks are affected by alteration and post-magmatic process, spilitization, weak thermal metamorphism and hydrothermal alteration. The major element contents may have been modified, mainly for alkalies, $\mathrm{CaO}$, and, sometimes, MgO. The basalts and gabbros have the following range in composition: $46.7<\mathrm{SiO}_{2} \%<55.4$, $0.7<\mathrm{TiO}_{2} \quad \%<1.0, \quad 9.4<\mathrm{MgO} \quad \%<10.5, \quad 0.36<\mathrm{MgO} / \mathrm{MgO}+\mathrm{FeOt}<0.54, \quad$ and $1.2<\mathrm{Na}_{2} \mathrm{O}+\mathrm{K}_{2} \mathrm{O}<3.7$. Normative compositions are fairly saturated (Qtz $\left.=0-1.7\right)$ to oversaturated ( $\mathrm{Ne}=0.1$ in the more mafic sample). Normative olivine ranges from 20 to 0 (consistent with the $\mathrm{MgO}$ contents), but no olivine is observed in the thin sections. One gabbro is characterized by high MgO-content and low alkali-content, consistent with its pyroxene cumulate texture. The same features are fully expressed by the cumulate pyroxenites, with $\mathrm{MgO}$ ranging from 19.5\% to 21.4\%. Spilites show high loss on ignition and 
moderate $\mathrm{Na}$ enrichment. They are mafic $\left(42.7<\mathrm{SiO}_{2} \%<46.4\right)$ and enriched in $\mathrm{Ti}$ $\left(1.2<\mathrm{TiO}_{2} \%<2.3\right)$.

Table 1. : Chemical analyses of the mafic rocks of the Zalbi Group. M-Gb, metagabbro; M-Bs, metabasalt; MPx, metapyroxenite; M-Sp, metaspilite. Major elements analysed by ICP-OES, and minor elements by ICP-MS, at the analytical laboratory of the CRPG-CNRS center of Nancy, France

\begin{tabular}{|c|c|c|c|c|c|c|c|c|c|c|c|c|c|}
\hline $\begin{array}{l}\# \\
\text { Rock } \\
\text { Loc } \\
\end{array}$ & $\begin{array}{l}\text { LER-115 } \\
\text { M-Gb } \\
\text { N-Léré } \\
\end{array}$ & $\begin{array}{l}\text { LER-43 } \\
\text { M-Gb } \\
\text { N-Léré }\end{array}$ & $\begin{array}{l}\text { Pag-S2-8 } \\
\text { M-Bs } \\
\text { Gouey goudoum }\end{array}$ & $\begin{array}{l}\text { LER-50 } \\
\text { M-Gab } \\
\text { SW-Lake }\end{array}$ & $\begin{array}{l}\text { LER-51 } \\
\text { M-Gab } \\
\text { SW-Lake } \\
\end{array}$ & $\begin{array}{l}\text { LER-46 } \\
\text { M-Gab } \\
\text { S-Léré }\end{array}$ & $\begin{array}{l}\text { LER-116 } \\
\text { M-Px } \\
\text { N-Léré } \\
\end{array}$ & $\begin{array}{l}\text { LER-1 } 14 \\
\text { M-Px } \\
\text { N-Léré } \\
\end{array}$ & $\begin{array}{l}\text { LER-124 } \\
\text { M-Px } \\
\text { SW-Lake }\end{array}$ & $\begin{array}{l}\text { LER-125 } \\
\text { M-Px } \\
\text { SW-Lake } \\
\end{array}$ & $\begin{array}{l}\text { LER-175 } \\
\text { M-Sp } \\
\text { Zalbi } \\
\end{array}$ & $\begin{array}{l}\text { LER-176 } \\
\text { M-Sp } \\
\text { Zalbi } \\
\end{array}$ & $\begin{array}{l}\text { LER-187 } \\
\text { M-Sp } \\
\text { SW-Lake }\end{array}$ \\
\hline$\overline{\mathrm{SiO}_{2}}$ & 46.73 & 48.44 & 46.72 & 47.02 & 51.91 & $\begin{array}{l}55.41 \\
\end{array}$ & 41.43 & 42.06 & 43.74 & 45.62 & 45.98 & 46.42 & 42.74 \\
\hline $\begin{array}{l}\mathrm{TiO}_{2} \\
\mathrm{Al}_{2}\end{array}$ & 0.84 & 0.84 & 0.99 & & 0.71 & 0.98 & 0.50 & $\begin{array}{r}0.83 \\
0.08\end{array}$ & 0.26 & 0.28 & 1.20 & 2.33 & 2.16 \\
\hline $\mathrm{Al}_{2} \mathrm{O}_{3}$ & 17.40 & 16.66 & 14.13 & 17.60 & 13.31 & 7.25 & 7.65 & 10.08 & 3.36 & 6.00 & 14.02 & 14.14 & 13.53 \\
\hline $\mathrm{Fe}_{2} \mathrm{O}_{3} \mathrm{t}$ & 8.85 & 9.40 & 10.99 & 12.44 & 10.16 & 10.44 & 17.80 & 12.62 & 20.36 & 18.50 & 11.90 & 13.24 & 12.39 \\
\hline $\mathrm{MnO}$ & 0.12 & 0.12 & 0.14 & 0.21 & 0.21 & 0.36 & 0.27 & 0.18 & 0.24 & 0.29 & 0.17 & 0.23 & 0.26 \\
\hline $\mathrm{MgO}$ & 9.38 & 8.36 & 5.95 & 6.26 & 8.30 & 10.50 & 19.47 & 20.97 & 19.81 & 21.41 & 7.18 & 5.65 & 4.27 \\
\hline $\mathrm{CaO}$ & 11.08 & 9.91 & 7.99 & 9.72 & 10.68 & 12.03 & 7.98 & 6.99 & 8.84 & 3.34 & 10.24 & 8.91 & 10.03 \\
\hline $\mathrm{Na}_{2} \mathrm{O}$ & 2.05 & 2.85 & 3.47 & 1.88 & 2.14 & 1.02 & 0.21 & 0.36 & 0.06 & 0.09 & 2.54 & 4.32 & 3.12 \\
\hline $\mathrm{K}_{2} \mathrm{O}$ & 1.06 & 0.83 & 0.16 & 1.63 & 0.79 & 0.14 & 0.00 & 0.00 & 0.00 & 0.00 & 0.17 & 0.06 & 0.96 \\
\hline $\mathrm{P}_{2} \mathrm{O}_{5}$ & 0.14 & 0.16 & 0.19 & 0.29 & 0.20 & 0.15 & 0.08 & 0.20 & 0.08 & 0.10 & 0.29 & 0.53 & 0.43 \\
\hline LOI & 2.24 & 2.31 & 9.10 & 1.91 & 1.44 & 1.61 & 4.43 & 5.73 & 3.08 & 4.22 & 6.12 & 4.33 & 10.03 \\
\hline Total & 99.89 & 99.88 & 99.83 & 99.87 & 99.85 & 99.89 & 99.82 & 100.02 & 99.83 & 99.85 & 99.81 & 100.16 & 99.92 \\
\hline $\mathrm{La}$ & 3.12 & 3.64 & 3.67 & 5.14 & 7.58 & 12.42 & 0.57 & 6.29 & 0.39 & 0.49 & 14.74 & 14.70 & 15.10 \\
\hline $\mathrm{Ce}$ & 9.09 & 8.62 & 9.49 & 12.62 & 20.06 & 33.18 & 1.36 & 15.30 & 1.12 & 1.80 & 31.02 & 39.10 & 37.90 \\
\hline $\mathrm{Pr}$ & 1.38 & 1.47 & 1.44 & 1.86 & 3.12 & 5.63 & 0.26 & 1.91 & 0.29 & 0.34 & 3.74 & 5.28 & 5.31 \\
\hline $\mathrm{Nd}$ & 6.72 & 7.20 & 7.28 & 9.51 & 14.36 & 27.27 & 1.53 & 9.30 & 1.87 & 1.95 & 16.39 & 25.50 & 25.90 \\
\hline $\mathrm{Sm}$ & 2.21 & 2.30 & 2.48 & 2.65 & 4.02 & 8.25 & 0.56 & 2.41 & 0.77 & 0.69 & 4.09 & 6.59 & 6.46 \\
\hline Eu & 0.94 & 0.90 & 0.95 & 0.97 & 1.05 & 1.31 & 0.24 & 0.82 & 0.16 & 0.14 & 1.35 & 2.33 & 2.37 \\
\hline Gd & 2.53 & 2.24 & 3.31 & 3.03 & 4.38 & 9.01 & 0.76 & 2.66 & 1.05 & 0.91 & 3.64 & 6.87 & 6.44 \\
\hline $\mathrm{Tb}$ & 0.36 & 0.35 & 0.55 & 0.53 & 0.65 & 1.42 & 0.13 & 0.39 & 0.17 & 0.15 & 0.59 & 1.03 & 1.05 \\
\hline Dy & 2.20 & 2.11 & 3.63 & 3.21 & 3.97 & 8.64 & 0.85 & 2.22 & 1.07 & 1.00 & 3.49 & 6.34 & 6.41 \\
\hline Ho & 0.50 & 0.41 & 0.80 & 0.67 & 0.93 & 1.83 & 0.19 & 0.46 & 0.24 & 0.22 & 0.72 & 1.27 & 1.42 \\
\hline $\mathrm{Er}$ & 1.22 & 0.99 & 2.21 & 1.89 & 2.52 & 5.01 & 0.51 & 1.18 & 0.61 & 0.64 & 0.72 & 3.42 & 3.73 \\
\hline $\mathrm{Tm}$ & 0.15 & 0.16 & 0.35 & 0.30 & 0.39 & 0.78 & 0.08 & 0.17 & 0.10 & 0.11 & 0.32 & 0.50 & 0.55 \\
\hline $\mathrm{Yb}$ & 1.10 & 0.90 & 2.23 & 2.07 & 2.71 & 5.41 & 0.57 & 1.11 & 0.62 & 0.76 & 1.97 & 3.22 & 3.65 \\
\hline Lu & 0.18 & 0.15 & 0.36 & 0.29 & 0.42 & 0.77 & 0.09 & 0.17 & 0.09 & 0.12 & 0.29 & 0.49 & 0.54 \\
\hline $\mathrm{Ba}$ & 44 & 59 & 43 & 193 & 77 & 36 & 8 & 23 & 5 & 9 & 100 & 57 & 153 \\
\hline Co & 44 & 42 & 36 & 40 & 39 & 36 & 117 & 77 & 114 & 125 & 40 & 39 & 33 \\
\hline $\mathrm{Cr}$ & 668 & 371 & 101 & 63 & 366 & 275 & 289 & 1813 & 144 & 140 & 515 & 101 & 60 \\
\hline $\mathrm{Cu}$ & 65.4 & 42.0 & 125.0 & 362.3 & 79.4 & 60.9 & 24.5 & 119.0 & 26.5 & 173.0 & 73.1 & 72.0 & 30.0 \\
\hline $\mathrm{Ga}$ & 15.3 & 16.1 & 16.7 & 19.2 & 14.6 & 10.5 & 8.6 & 11.9 & 5.7 & 7.6 & 16.5 & 22.9 & 25.0 \\
\hline $\mathrm{Hf}$ & 1.36 & 1.11 & 1.68 & 0.86 & 2.84 & 3.01 & 0.24 & 1.25 & 0.22 & 0.41 & 1.85 & 3.42 & 4.17 \\
\hline $\mathrm{Nb}$ & 2.10 & 2.65 & 2.11 & 1.23 & 2.83 & 5.40 & 0.30 & 4.16 & 0.20 & 0.29 & 2.02 & 5.28 & 6.04 \\
\hline $\mathrm{Ni}$ & 218.0 & 246.4 & 39.8 & 28.5 & 72.0 & 80.0 & 217.0 & 747.0 & 237.0 & 286.0 & 95.0 & 29.7 & 23.8 \\
\hline $\mathrm{Pb}$ & 1.09 & 2.27 & 1.38 & 1.58 & 3.48 & 1.21 & 0.00 & 0.00 & 0.00 & 0.00 & 4.61 & 3.18 & 1.83 \\
\hline $\mathrm{Rb}$ & 26.50 & 20.36 & 2.69 & 45.83 & 13.79 & 1.26 & 0.50 & 0.90 & 0.50 & 0.50 & 4.33 & 3.50 & 18.70 \\
\hline $\mathrm{Sr}$ & 496 & 445 & 164 & 287 & 260 & 169 & 36 & 75 & 12 & 10 & 603 & 363 & 242 \\
\hline $\mathrm{Ta}$ & 0.16 & 0.19 & 0.15 & 0.08 & 0.20 & 0.46 & 0.02 & 0.30 & 0.02 & 0.02 & 0.14 & 0.36 & 0.38 \\
\hline $\mathrm{Th}$ & 0.20 & 0.19 & 0.38 & 0.28 & 0.97 & 3.71 & 0.10 & 0.20 & 0.10 & 0.10 & 1.21 & 0.70 & 0.94 \\
\hline $\mathrm{U}$ & 0.10 & 0.11 & 0.14 & 0.12 & 0.45 & 0.97 & 0.00 & 0.10 & 0.00 & 0.00 & 0.72 & 0.24 & 0.30 \\
\hline $\mathrm{v}$ & 158 & 153 & 276 & 337 & 244 & 202 & 293 & 141 & 273 & 165 & 263 & 343 & 356 \\
\hline $\mathrm{Y}$ & 13.10 & 11.08 & 22.80 & 18.63 & 26.40 & 49.61 & 5.27 & 12.90 & 6.26 & 6.46 & 20.24 & 36.40 & 38.80 \\
\hline $\mathrm{Zr}$ & 61 & 40 & 59 & 26 & 94 & 84 & 7 & 54 & 7 & 13 & 76 & 163 & 190 \\
\hline
\end{tabular}

Basalts and gabbros have a very low rare earth element (REE) fractionation, $(\mathrm{La} / \mathrm{Yb})_{N}=1.2-$ 2.9, moderate negative $\mathrm{Nb}$ - and Ta-anomalies, $(\mathrm{Nb} / \mathrm{La})_{N}=0.4-0.7$ and 0.2 for one sample, variable Th patterns, $(\mathrm{Th} / \mathrm{La})_{N}=0.4-1.0$, moderate Ba-enrichment, and random contents of $\mathrm{Rb}$ (Fig. 7). Some Ti-negative anomalies may be due to mineral fractionation. The cumulate pyroxenites exhibit an overall depletion of the incompatible elements that is explained by the dilution effect. The spilites are slightly more fractionated, $(\mathrm{La} / \mathrm{Yb})_{N}=3.0-5.4$, depleted in $\mathrm{Nb}$ and Ta, $(\mathrm{Nb} / \mathrm{La})_{N}=0.1-0.4$, and in Th, $(\mathrm{Th} / \mathrm{La})_{N}=0.4-0.7$.

Geochemically, the Zalbi mafic rocks compare poorly with N-MORB and island arc tholeiite (IAT), which are more depleted in the most incompatible elements (Fig. 7B). They show some similarity with basalts from the Sea of Japan (BABB), a back-arc basin above a thinned continental crust, but the Zalbi rocks are clearly enriched in the most incompatible elements. Similarly, their profiles mirror the average continental tholeiite profile (CT); however, the Zalbi rocks are less enriched. Thus, the Zalbi Group basaltic rocks have geochemical patterns intermediate between those of the back-arc basin basalts and of the continental tholeiites. 

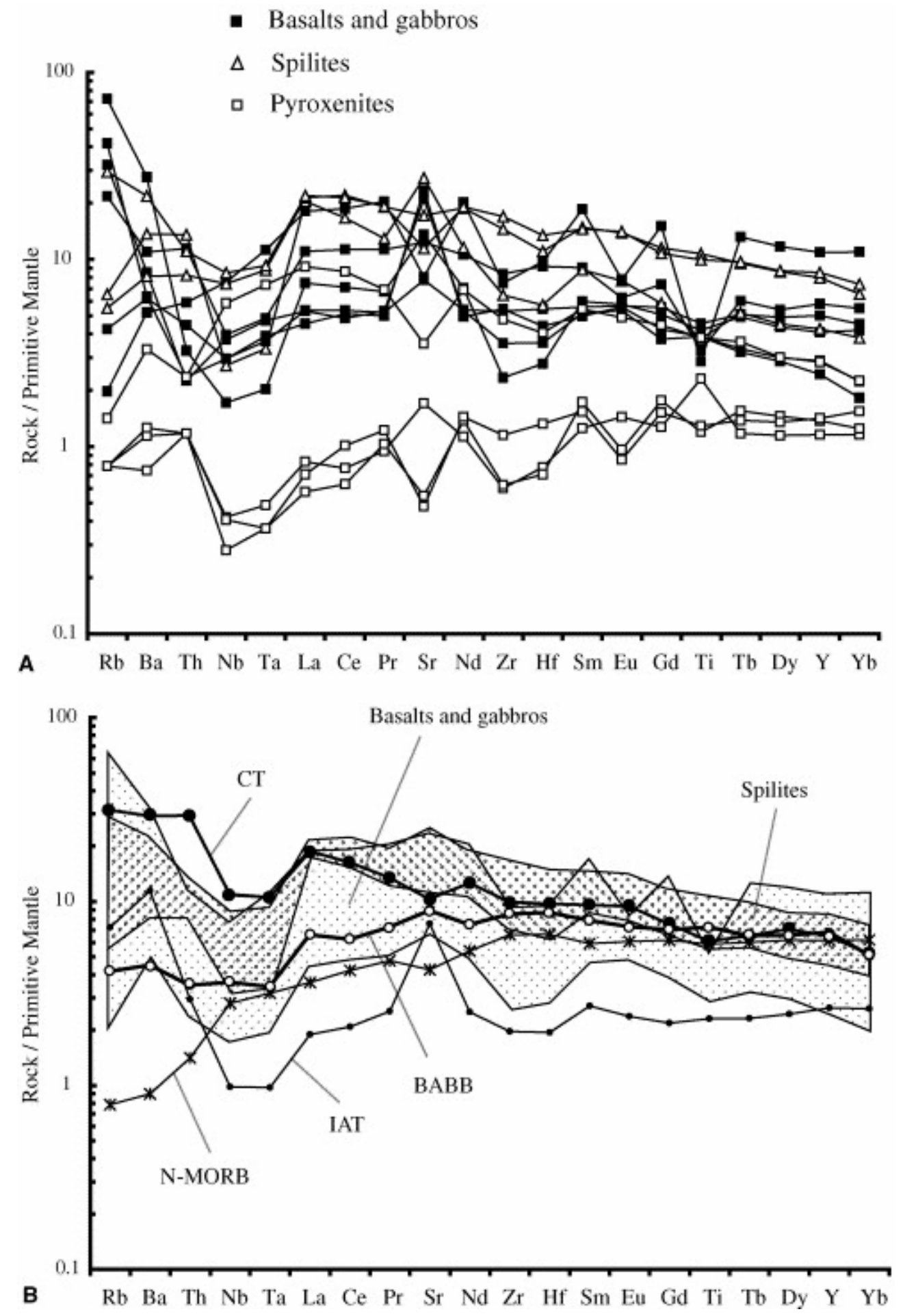

Fig. 7. Primitive Mantle normalized diagrams of mafic rocks of the Zalbi Group. Normalizing values after Sun and McDonough (1989). A, individual profiles of (meta) basalts, gabbros, spilites and pyroxenites. B, Comparison of basalts-gabbros and spilites with average profiles of continental tholeiites (CT after Holm, 1985), back-arc basin basalts, island arc tholeiites (BABB and IAT after Pouclet et al., 1995, and unpublished data) and N-MORB (after Sun and McDonough, 1989). 


\subsection{The pre-tectonic intrusions of gabbro-diorites (G1)}

\subsubsection{Petrography}

The proto-mylonitic granulation and recrystallization has variably modified the magmatic texture of the G1 gabbros and diorites. The best-preserved gabbroic rocks, with their primary magmatic minerals, are seen in the Boloro block. The texture is allotriomorphic coarse grained and consists of diopsidic clinopyroxene (Mg\% 45.6-48.2, Fe\% 13.7-16.6, Ca\% 36.338.1), amphibole Mg-tschermakite to Mg-hastingsite, plagioclase An51-72, less abundant potassium feldspar, Mg-biotite flakes $\left(\mathrm{XMg}(\mathrm{Mg} / \mathrm{Mg}+\mathrm{Fe})=0.53-0.60 ; \mathrm{TiO}_{2} \%=2.2-2.5\right)$, quartz, magnetite, ilmenite, and apatite. The pyroxene has low $\mathrm{Na}$ and $\mathrm{Al}$ contents (Ac\% 1.43.4; Jd\% 0.3-3.2) and is devoid of Ti. It is partly replaced by Mg-hornblende and wrapped with sheaves of cummingtonite and actinolitic hornblende of secondary origin. Local occurrences of plagioclase-rich cumulate zones also occur.

In the heavily tectonized blocks of Mourbamé and Guémou, the magmatic minerals have been recrystallized, diopside to hornblende and actinolite, plagioclase to albite and epidote $(\mathrm{Cz} \%$, 75), and biotite to pycnochlore.

The dioritic massif of Guégou is less deformed in its inner part. Here, the texture is granular and consists of magmatic amphibole Mg-hastingsitic hornblende, Mg-biotite (XMg $=0.52$ 0.58; $\mathrm{TiO}_{2} \%=1.5-2.8$ ), plagioclase, potassium feldspar, clinozoisite, titanite, quartz, magnetite and apatite.

In the $\mathrm{FeOt} / \mathrm{MgO} / \mathrm{Al}_{2} \mathrm{O}_{3}$ diagram of Rossi and Chèvremont (1987), the magmatic biotites analyzed in the G1 gabbro-diorites belong to the calc-alkaline association of granitoids (Fig. 8). The preserved magmatic paragenesis of these gabbros and diorites allows use of the barometer of Al-in-amphibole (Schmidt, 1992). We used the core composition of the magmatic amphibole. Calculated pressures, at \pm 0.6 kbars, are 7.7-6.8 kbars in the gabbro of Guémou, 4.9-5.2 kbars in the gabbro of Boloro, and 4.2-4.5 kbars in the diorite of Guégou. 


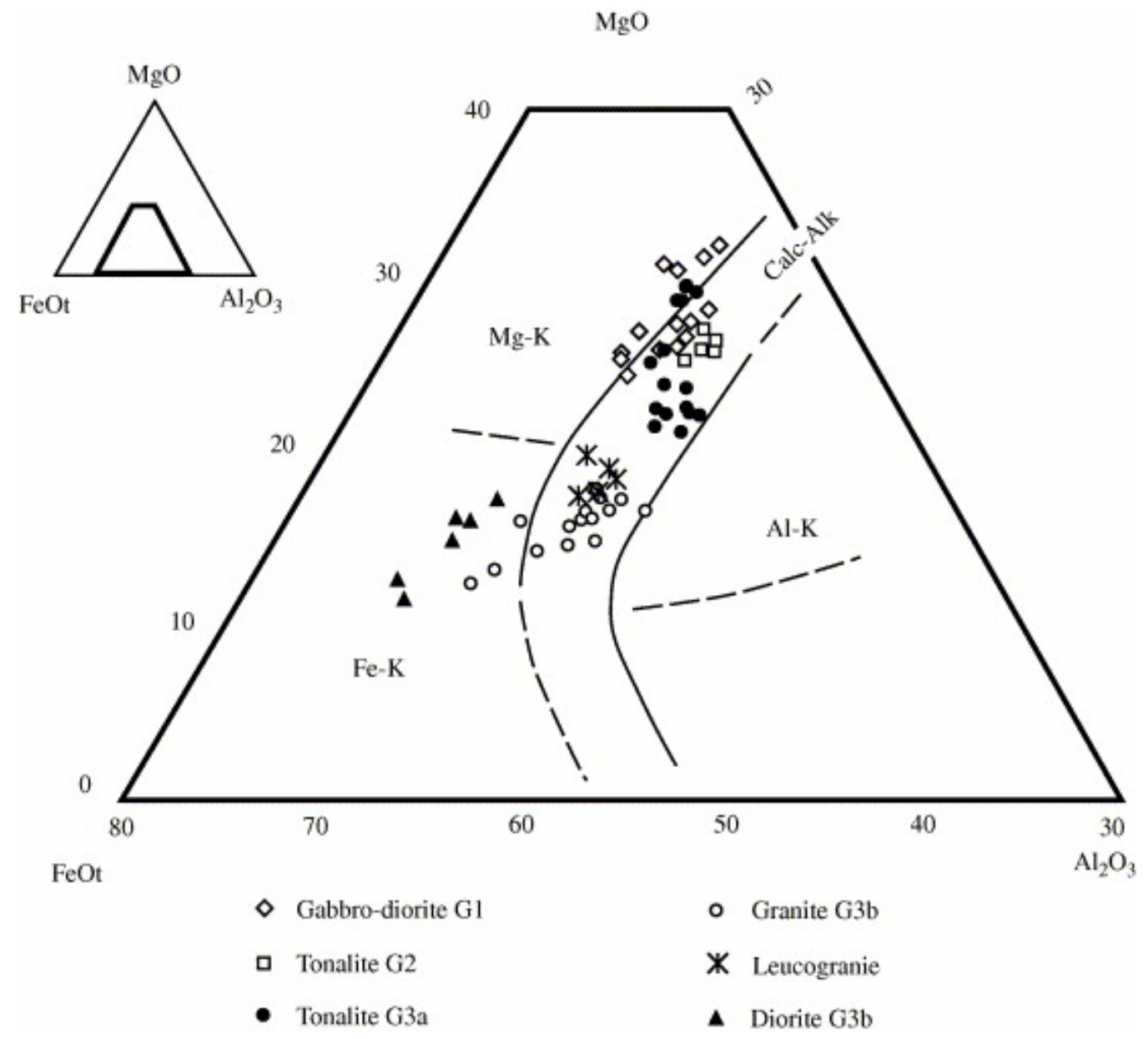

Fig. 8. FeOt-MgO- $\mathrm{Al}_{2} \mathrm{O}_{3}$ diagram of biotites of igneous rocks, after Rossi and Chèvremont (1987), in order to determine the magmatic association of the host-rock. Four main associations related to convergent tectonic domains are distinguishable: calc-alkaline (Calc-Alk), magnesio-potassic (Mg-K), ferro-potassic (Fe-K), and alumino-potassic (Al-K).

\subsubsection{Geochemistry}

The less deformed rocks of Mourbamé (one gabbro), Boloro (three gabbros), Guémou (one gabbro) and Guégou (one diorite), and the contaminated zone of the Guémou intrusion were selected for chemical analyses (Table 2). The major element contents of the gabbros are: $54.1<\mathrm{SiO}_{2} \%<58.4, \quad 0.8<\mathrm{TiO}_{2} \%<1.4,4.3<\mathrm{MgO} \%<2.4, \quad 4.6<\mathrm{Na}_{2} \mathrm{O}+\mathrm{K}_{2} \mathrm{O} \%<5.4$. The alkaline ratio indicates a moderate potassic composition $\left(1.1<\left(2 x \mathrm{~K}_{2} \mathrm{O}\right) / \mathrm{Na}_{2} \mathrm{O}<1.5\right)$. According to the norm calculation, the rocks are over-saturated $(5.2<\mathrm{Qtz}<11.3)$. The trace element patterns (Fig. 9A) exhibit a moderate fractionation $\left(3.0<(\mathrm{La} / \mathrm{Yb})_{N}<13.0\right)$, a moderate $\mathrm{Nb}$ - and Ta-negative anomaly $\left(0.4<(\mathrm{Nb} / \mathrm{La})_{N}<0.5\right)$, no or slight Th-enrichment $\left(0.6<(\mathrm{Th} / \mathrm{La})_{N}<1.5\right)$, weak enrichment in $\mathrm{Ba}$ and $\mathrm{Rb}$, a slight Ti-negative anomaly $\left(0.5<\left(\mathrm{Ti} / \mathrm{Ti}^{3}\right)_{N}<0.8\right)$, and no Eu anomaly. The weak enrichment in $\mathrm{Sr}$ can be due to plagioclase accumulation. 
Table 2. : Chemical analyses of the igneous rocks of the groups 1 to 3 . Same method as for Table 1

\begin{tabular}{|c|c|c|c|c|c|c|c|c|c|c|c|c|c|c|c|c|c|c|c|c|c|}
\hline \multirow{4}{*}{$\begin{array}{l}\text { Grousp } \\
\text { I } \\
\text { Rock } \\
\text { Looation }\end{array}$} & \multicolumn{7}{|l|}{$\mathrm{G}_{1}$} & \multicolumn{2}{|l|}{ G2 } & \multicolumn{2}{|l|}{ O3n } & \multicolumn{10}{|l|}{030} \\
\hline & LER: 53 & LER 201 & LER 204 & LER:160 & LER-70 & LER-73 & LER-183 & LER-216 & LER 226 & LER:SS & 5 LER 20 & LER-194 & 4 LER 152 & 2 LER $\$ 2$ & LER \&7 & LER -33 & 3 LER-18 & of LER-22z & 12 LER -227 & 6 LER 4 & LERS \\
\hline & Gabbro & Quacabbro & $\begin{array}{l}\text { - contaminated } \\
\text { Gabbro }\end{array}$ & Ad Qtzatabloo & Qzacabbro & Qtacabbro & o Dosite & Tonalite & Tomalite & Tonalie & e Troosh jentite & $\begin{array}{l}\text { = Moceso } \\
\text { granite }\end{array}$ & Graix & $A_{p}=\sum_{x}$ & Pegmaix & $x$ Granite & c Cranite & Ganite & $\begin{array}{l}\text { Lesoon } \\
\text { granite }\end{array}$ & PXdioriti & c Dorite \\
\hline & S-Mourtame & Gximos & Gxinnsu & Bolbero niver & If Baldero & W-Bdono & Gxigos & East Guarthot & 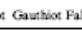 & 11. Lampoo & Mabudge & NELLéré & é Léré & SW-Léé & ¿ NELLéré & zatiel & Zatail & Funge & Boularé & N.Pala & N.Pala \\
\hline $\mathrm{so}_{2}$ & 54.13 & $\$ 4.46$ & 4.4.46 & 57.77 & 8.07 & 9.43 & 6404 & Q.44 & $\cos$ & 65.79 & 8.02 & 60.4 & 70.06 & 75.31 & 76.02 & 3.74 & 76.12 & 7596 & 74.2 & 58.63 & 63.03 \\
\hline $\mathrm{TO}_{2}$ & 1.12 & 0.81 & 138 & 1.06 & 1.05 & 105 & 0.57 & 0.57 & 0.54 & 0.44 & 031 & 0.54 & 0.38 & 0.09 & 0.00 & 0.18 & 0.13 & 0.13 & 0.08 & 134 & 091 \\
\hline$O_{3}$ & 18.75 & 1682 & 20.86 & 15.62 & 16.41 & 16.28 & 1608 & 18.58 & 16994 & 1731 & 1730 & 1582 & 14.72 & 14.73 & 13.46 & 13.47 & 12.00 & 1224 & 14.42 & 1605 & 16.23 \\
\hline Ont & 9.28 & 880 & 9.73 & 7.46 & 727 & 724 & 4.29 & 433 & 490 & 380 & 293 & 4.52 & 3.46 & 1.04 & 0.06 & 248 & 1.44 & 207 & 131 & 934 & 6.16 \\
\hline $\operatorname{MaO}$ & 0.16 & 0.16 & 0.10 & 0.10 & 0.09 & 0.00 & 0.05 & 0.05 & 0.06 & 0.05 & 0.000 & 0.066 & 0.03 & 0.000 & 0.000 & 0.00 & 0.03 & 0.04 & 0.00 & 0.11 & 0.07 \\
\hline $\mathrm{MgO}$ & 241 & 4.29 & 284 & 4.06 & 398 & 4.07 & 1.90 & 1.47 & 1.71 & 1.04 & 0.76 & 1.35 & 0.80 & 0.29 & 0.00 & 0.00 & 0.00 & 0.00 & $0 \mathfrak{x}$ & 1.39 & 1.40 \\
\hline $\mathrm{CaO}$ & 724 & 7.46 & 9.20 & 5.71 & 6.53 & 691 & 406 & 5.10 & 4.72 & 425 & 3.54 & 3.55 & 3.10 & 0.39 & 0.61 & 0.25 & 0.08 & 0.61 & 1.46 & 485 & 336 \\
\hline $\mathrm{N}_{2} \mathrm{O}$ & 3.05 & 284 & 4.30 & 3.16 & 3.59 & 357 & 4.63 & 585 & 4.70 & 5.53 & 5.63 & 396 & 3.15 & 5.58 & 3.41 & 409 & 3.76 & 4.20 & 43 & 408 & 4.40 \\
\hline${ }_{2} \mathrm{O}$ & 235 & 1.76 & 0.97 & 2.11 & 1.84 & 1.80 & 1.85 & 0.67 & 1.13 & 1.08 & 0.89 & 243 & 3.07 & 1.62 & 5.29 & 5.15 & 500 & 3.89 & 208 & 3.56 & 383 \\
\hline $\mathrm{P}_{2} \mathrm{O}_{\mathrm{s}}$ & 0.52 & 0.21 & 0.23 & 0.37 & 0.36 & 0.37 & 0.15 & 0.21 & 0.21 & 0.17 & 0.16 & 0.21 & 0.16 & 0.07 & 0.00 & 0.00 & 0.06 & $\cos$ & $0.0 \pi$ & o.ss & 0.28 \\
\hline or & 0.93 & 226 & 285 & 248 & 0.74 & 0.12 & 227 & 0.65 & 194 & 0.42 & 0.35 & 0.72 & 1.02 & 0.79 & 0.29 & 0.34 & 0.5 & 0.00 & 1.04 & 0.06 & 0.23 \\
\hline 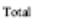 & 9994 & 9987 & 9982 & 9990 & $\$ 993$ & 993 & 9989 & 992 & 990 & 99.88 & 9989 & 99.90 & 9995 & 9991 & 99.74 & 99.70 & 10000 & 99.79 & 9990 & 9996 & 9990 \\
\hline L & 14.14 & 1200 & 587 & 28.40 & 2350 & 3430 & 1210 & 11.80 & 4.29 & 1336 & 687 & 3820 & 41.80 & 1.61 & 2.15 & $3 ., \infty 0$ & $\cos \theta$ & 30.10 & 5.72 & $\cos 0$ & 58.40 \\
\hline c & 35.17 & 25.50 & 1200 & 65.60 & $\$ 490$ & 56.10 & 3050 & 25.60 & 8.43 & 3271 & 15.40 & 6650 & 8030 & 3.15 & 3.43 & 84.40 & 11200 & 74.60 & 1250 & 129.00 & 12500 \\
\hline $\mathrm{Pr}$ & 506 & 336 & 190 & 8.12 & 701 & 7.03 & 396 & 3.58 & 1.12 & 4.20 & 197 & 8.12 & 8.51 & 0.45 & 0.41 & w0.10 & $15 x$ & 1050 & 1.86 & 1600 & 1520 \\
\hline Nd & 1700 & 1420 & 9.61 & 3390 & $\$ 20$ & ×.70 & 1680 & 15.10 & 5.11 & 1607 & 794 & 29.50 & 31.50 & 1.81 & 1.48 & 36.40 & 57.0 & 48.40 & 637 & 61.00 & 5430 \\
\hline $\mathrm{Sm}$ & 627 & 3.43 & 296 & 627 & 5.06 & S.C6 & 3.76 & 3.08 & 1.19 & 3.01 & 1.34 & 5.67 & 5.44 & 0.37 & 0.48 & 7.49 & $11 . x$ & 1390 & 1.13 & 1240 & 9.88 \\
\hline $\mathrm{Ea}$ & 192 & 1.11 & 1.05 & 1.57 & 1.66 & 1.71 & 1.11 & 1.05 & 0.46 & 0.87 & 0.09 & 1.27 & 1.22 & 0.10 & 0.27 & 0.51 & 0.28 & 2.15 & 0.31 & 327 & 1.81 \\
\hline & 601 & 350 & 3.43 & 4.78 & 431 & 4.66 & 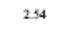 & 234 & it & 239 & مor & 4.21 & 40 & 0.27 & $0 . x$ & 6.46 & $10 x$ & 1330 & 0.84 & 10.0 & 8.46 \\
\hline $\mathrm{Tb}$ & 0.97 & 0.56 & 0.57 & 0.67 & 0.00 & 0.61 & 0.36 & 0.31 & 0.15 & 0.30 & 0.11 & 0.86 & 0.51 & 0.04 & 0.18 & 1.12 & 1.78 & 234 & 0.11 & 1.59 & 1.25 \\
\hline Dy & 5.68 & 3.58 & 3.64 & 3.62 & 3.29 & 3.20 & 192 & 1.67 & 0.81 & 1.09 & o.ss & 3.66 & 251 & 0.21 & 1.42 & 706 & 10.0 & 1430 & 0.5 & 8.29 & 6.63 \\
\hline H & 1.17 & 0.74 & 0.84 & 0.62 & 0.56 & 0.00 & 030 & 0.30 & 0.15 & 0.30 & 0.09 & 0.74 & 0.46 & 0.03 & 0.38 & 1.50 & 238 & 3.07 & 0.00 & 1.00 & 1.30 \\
\hline Er & 3.23 & 207 & 2.11 & 1.57 & 1.43 & 1.53 & 0.72 & 0.77 & 0.41 & 0.79 & 0.24 & 192 & 1.28 & 0.09 & 1.16 & 4.04 & $\infty$ & 891 & 0.28 & 4.1 & 3.45 \\
\hline $\mathrm{Tm}$ & 0.49 & 0.35 & 0.33 & 0.24 & 0.21 & & & & 0.06 & ou & & 0.09 & 0.19 & 0.02 & . & 0.65 & & & 0.04 & 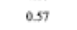 & 0.53 \\
\hline $\mathrm{Yb}$ & 3.44 & 228 & 202 & 1.57 & 1.36 & 1.34 & 0.76 & 0.67 & 0.35 & 0.99 & 0.23 & 1.89 & 1.34 & 0.10 & 1.24 & 4.53 & 734 & 956 & 0.3 & 3.70 & 3.14 \\
\hline Lu & 0.52 & 0.36 & 0.28 & 0.21 & 0.22 & 0.22 & 0.11 & 0.11 & 0.06 & 0.17 & 0.04 & 0.28 & 0.24 & 0.02 & 0.20 & 0.65 & 1.08 & 1.45 & 0.00 & 0.64 & $0.5 s$ \\
\hline $\mathrm{Ba}$ & 742 & 437 & 19 & 446 & 437 & 479 & Ses & 50 & 584 & 330 & $\pi 2$ & 836 & 1328 & 1353 & 170 & 297 & 240 & 876 & 1225 & 998 & 1320 \\
\hline a & 18.7 & 200 & $x_{2}$ & 24.1 & 2.6 & 3.4 & 117 & 9 & w.1. & 6.6 & 43 & 9.2 & ss & 20 & o. & 13 & 0.9 & 10 & 10 & 168 & 126 \\
\hline$\alpha$ & 203 & a.S & 23 & 1370 & 1260 & 1370 & 532 & 33. & 16.6 & 9.7 & 89 & 21.8 & 11.2 & 7.4 & 64 & 123 & 178 & 350 & 0.0 & 13.7 & 149 \\
\hline$\infty$ & 91.2 & 49 & 8.1 & 81.1 & 799 & 8.4 & 109 & 75 & 153 & 11.4 & 68 & 21.9 & 29.2 & 0.0 & 99 & 124 & 5.2 & 93 & 0.6 & 22.6 & 26.4 \\
\hline $\mathrm{c}_{\mathrm{a}}$ & 200 & 19.0 & 8.4 & 20.5 & D.1. & 19.6 & 231. & 2.S. & $D .4$ & 21.9 & 220 & 19.8 & 16.5 & 15.5 & 133 & 199 & 23.1 & 24.1 & 18.2 & 29.7 & 25.6 \\
\hline Hr & 5.70 & 254 & 288 & 3.56 & 4.82 & 393 & 337 & 305 & 222 & 3.31 & 267 & 628 & 599 & 1.34 & 201 & 883 & 9.86 & 895 & 1.2 & 9.98 & 1280 \\
\hline $\mathrm{N}$ & 793 & 539 & 3.45 & 1200 & $\infty .00$ & 10.40 & 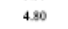 & & 0.88 & 4.58 & & 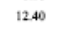 & 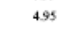 & 0.95 & 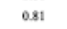 & coso & 2780 & 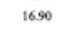 & 280 & 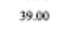 & 39.10 \\
\hline $\mathrm{N}$ & 14.6 & 34.8 & 36.5 & 83.4 & 7.4 & 4.5. & 261 & 13.5 & 140 & 78 & 0.0 & 10.4 & N & 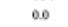 & 0.0 & 83 & 9.7 & 180 & 0.0 & 10.1 & 119 \\
\hline $\mathrm{P}=$ & 4.45 & 4.16 & 237 & 5.15 & 5.00 & 480 & 6.38 & 4.9 & 607 & 6.76 & 4.63 & 6.61 & 7.45 & 4.82 & 1580 & 15.00 & 11.90 & 9.48 & $9 . x$ & 14.70 & 1790 \\
\hline $\mathrm{Rb}$ & 43.00 & 46.20 & 20.00 & 43.70 & 3530 & 2020 & 3120 & 733 & 15.60 & 18.04 & 1180 & 6830 & 47.10 & 19.50 & 110.00 & 121000 & 14200 & 8800 & 49.90 & 9900 & 18200 \\
\hline $\mathrm{s} r$ & 479 & 308 & 344 & 584 & cos & 700 & $\omega 8$ & 1100 & 830 & 868 & $\$ 6$ & 377 & 351 & 340 & 61 & 8 & 18 & 41 & 366 & 440 & 300 \\
\hline $\mathrm{Ta}$ & 0.46 & 0.4 & 0.2 & 0.87 & 0.7 & 0.08 & 0.52 & 0.10 & 0.03 & 0.43 & 0.05 & 1.14 & 0.23 & 0.09 & 0.08 & 1.02 & $2 x$ & 136 & 0.18 & 285 & 3.26 \\
\hline $\mathrm{T}$ & 1.20 & 2.19 & 0.87 & 3.11 & 331 & 1.85 & 2 & 0.48 & 0.17 & 1.09 & 0.25 & 732 & $8 \pi$ & 0.72 & 1.10 & 00.70 & 11.80 & 631 & 0.0 & 9.44 & 18.00 \\
\hline v & 0.25 & 0.77 & 0.35 & 1.07 & 104 & 0.56 & 0.8 & 0.000 & 0.08 & 0.39 & 0.09 & 1.29 & 0.79 & 0.40 & 0.67 & 383 & 4.8 & 1.63 & 0.9 & 280 & 6.61 \\
\hline $\mathrm{v}$ & 118 & 203 & 14 & 157 & 151 & 18 & 80 & 75 & 8 & $s 2_{2}$ & 33 & $5 s$ & 37 & 15 & 2 & 3 & 3 & 4 & 8 & 99 & 61 \\
\hline 8 & 3481 & 2180 & 21.70 & 1830 & 16000 & 16800 & 9.2 & 889 & 5.01 & 9.66 & 284 & 2030 & 14.10 & 0.97 & 1220 & 4.10 & 7200 & 89.50 & $32 n$ & 45.10 & 38.80 \\
\hline & 245 & 100 & 12 & 163 & 211 & 181 & 134 & 141 & $\%$ & 123 & 121 & 287 & 244 & 47 & 46 & 275 & 281 & 256 & 38 & 385 & $\$ 18$ \\
\hline
\end{tabular}

These geochemical characteristics indicate a calc-alkaline orogenic magmatic signature. The contaminated sample of the Guémou gabbro border can be interpreted as a mixing product of the gabbro with the amphibolitic material derived from the metabasites of the Zalbi Group, that were the country rocks of the intrusion. The diorite is more evolved than the gabbros $\left(\mathrm{SiO}_{2} \%=64.0, \mathrm{Na}_{2} \mathrm{O}+\mathrm{K}_{2} \mathrm{O} \%=6.5\right)$, but, it shows the same calc-alkaline signature $\left((\mathrm{La} / \mathrm{Yb})_{N}=11.5,(\mathrm{Nb} / \mathrm{La})_{N}=0.4\right)$.

Very low contents of $\mathrm{Ti}$ and $\mathrm{Na}$ in pyroxenes are also consistent with a calc-alkaline orogenic setting for these rocks (Leterrier et al., 1982). Compared with the average composition of the Chili andesites (CAB, Fig. 9A), the gabbro-diorites show a similar profile, except for $\mathrm{Nb}$ and Ta which are more depleted in the Chili lavas. Meanwhile, an active margin geotectonic context can be suggested for the G1 gabbro setting. 

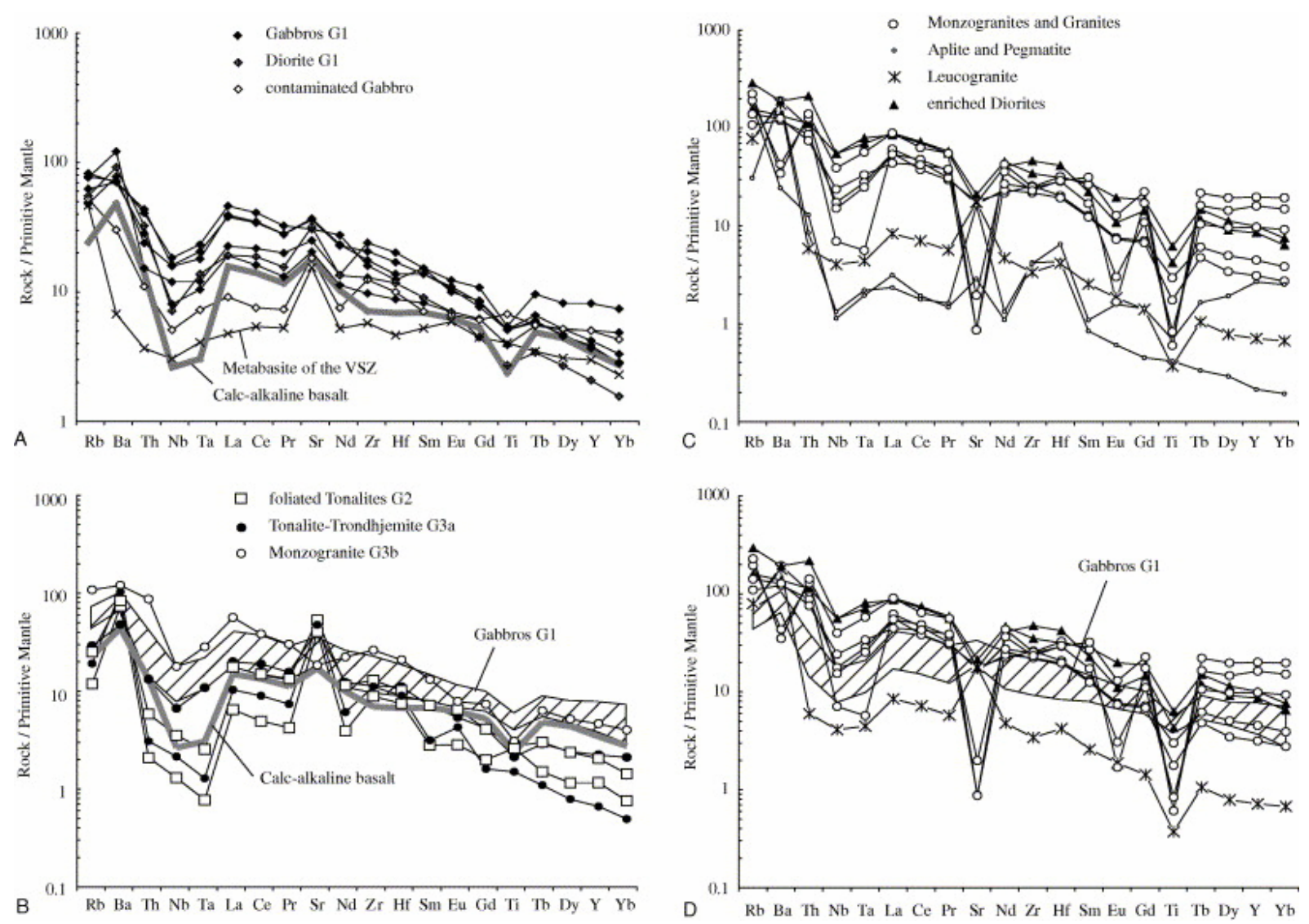

Fig. 9. Primitive Mantle normalized diagrams of the gabbro to granite rocks of the intrusive group bodies. Normalizing values after Sun and McDonough (1989). A, profiles of the gabbro-diorites G1. Selected profile of a metabasite of the Zalbi Group to test the contamination of the gabbro of Guémou. Average profile of the calcalkaline basalt of Chili, for comparison (after Thorpe et al., 1984, and Hickey et al., 1986). B, profiles of the tonalites and throndhjemites of groups G2 and G3a. Comparison with the monzogranite G3b and with the overall feature of the gabbros G1. C, profiles of the granitoids G3b. D, profiles of the granitoids G3b, excluding the evolved aplite and pegmatite, for comparison with the features of the gabbros G1.

\subsection{The Gauthiot fall foliated massif of tonalite (G2)}

\subsubsection{Petrography}

The best-preserved tonalites are observed in the NW part of the massif. The texture is coarse grained, with local accumulation of large plagioclase, and is overprinted by a planar fabric. Consequently, the original akeritic texture, characterized by early crystallization of the plagioclase phenocrysts, is only partly recognizable. Magmatic minerals include plagioclase (An 27-29), amphibole (Mg-hastingsite to hastingsitic hornblende), Mg-biotite (XMg $=0.55-$ 0.57; $\mathrm{TiO}_{2} \%=2.1-2.9$ ), titanite, Ti-rich magnetite with exsolutions of ilmenite and rutile, clinozoisite, interstitial quartz and potassium feldspar, and accessory apatite and zircon. However, in most of the massif, deformation and fluid transfer caused albitization of plagioclase, recrystallization of amphibole and biotite to actinolitic hornblende and pycnochlore, and formation of microgranular albite, actinolite, epidote, muscovite, quartz and calcite. In the Gauthiot Fall area, the mylonitization led to a complete replacement of the magmatic phases by secondary minerals. 
The magmatic biotite belongs to the calc-alkaline association of granitoids (Fig. 8). The paragenesis of the tonalite allows use of the barometer of Al-in-amphibole (Schmidt, 1992). Analyses of the cores of the magmatic amphiboles that crystallized during the pluton emplacement give pressures of 6.3 to $7.3 \pm 0.6$ kbars.

\subsubsection{Geochemistry}

A fresh tonalite sample from east of Mombaroua (Fig. 2), and a protomylonitic tonalite from the Gauthiot Fall were analysed (Table 2). The silica content averages $63 \%$. $\mathrm{TiO}_{2}$ and $\mathrm{MgO}$ are low. $\mathrm{Na}_{2} \mathrm{O}$ is high and $\mathrm{K}_{2} \mathrm{O}$ is low, the sodium prevalence being shown by the alkali ratio $\left(0.2<\left(2 x \mathrm{~K}_{2} \mathrm{O}\right) / \mathrm{Na}_{2} \mathrm{O}<0.5\right)$. The trace element profiles are fractionated $\left(8.7<(\mathrm{La} / \mathrm{Yb})_{N}<12.7\right)$, with a strong $\mathrm{Nb}$ - and Ta-negative anomaly $\left((\mathrm{Nb} / \mathrm{La})_{N}=0.2\right)$, and a Ba-enrichment (Fig. 9B). The Rb-enrichment is slight, whereas Th is rather depleted $\left((\mathrm{Th} / \mathrm{La})_{N}=0.3\right)$. In contrast, Sr has a strong positive anomaly that is not associated with a significant Eu anomaly. Because accumulation of plagioclase is frequent in tonalites, this can explain the Sr-enrichment if the plagioclase is devoid of divalent Eu. However, a sourcerelated Sr-enrichment is more likely. There is a good match with the chemistry of the average calc-alkaline basalt from the Chilean arc (Fig. 9B). Compared to the patterns of the G1 gabbro-diorites, the G2 tonalites show a strong depletion of heavy rare earth elements (HREE) and high field strength elements (HFSE), and a more important Nb- and Ta-negative anomaly. Thus, the two groups, G1 and G2, must have different sources. Depletion in HREE and HFSE is a well-known feature of Precambrian TTG-type (Tonalite-TrondhjemiteGranodiorite) magmas. It is explained by the presence of garnet as a residual phase during melting of garnet-bearing amphibolites in the source (Jahn et al., 1981 and Martin, 1993). Such an amphibolitic source is present in the subducted oceanic crust, but also in the mafic lower continental crust.

\subsection{The post-tectonic intrusions of batholith granitoids (G3)}

\subsubsection{Petrography}

The G3a magmatic rocks consist of tonalites, trondhjemites and granodiorites. The main petrographic facies of the G3b rocks is a biotite granite, but monzonitic granites are abundant. A pluton of muscovite- and biotite-bearing leucogranite crops out in the Boularé area, north of the Gauthiot Fall massif. The other facies include granodiorite, diorite, and pyroxene-diorite.

The G3a tonalites exhibit a typical akeritic texture with plagioclase phenocrysts. They can be associated in the same pluton with the granular textured granodiorites. Minerals include plagioclase (An 22-27), Mg-hastingsite, Mg-biotite ( $\mathrm{XMg}=0.47-0.54 ; \mathrm{TiO}_{2} \%=1.5-2.7$ ), allanite, clinozoisite $\left(\mathrm{Cz} \%\right.$ 69-75), titanite, Ti-magnetite $\left(\mathrm{TiO}_{2} \%=15-18\right)$, interstitial potassium feldspar and quartz, and accessory apatite and zircon. In the granodiorites, potassium feldspar is more developed and quartz is more abundant. In the trondhjemites, the plagioclase is more sodic (An 21-25), amphibole is less abundant, whereas interstitial potassium feldspar and quartz are more abundant. The barometer of $\mathrm{Al}$ in amphibole (Schmidt, 1992) calculated for the cores of the magmatic amphibole of tonalites, gives 5.4$6.5 \pm 0.6 \mathrm{kbars}$ for the level of emplacement.

The G3b granodiorites are quite similar to those of the G3a. The G3b monzogranites differ by the lack of amphibole and greater abundance of potassium feldspar and quartz. Plagioclase is sodic (An 18-26), and biotite is more ferrous $(\mathrm{XMg}=0.34-0.40)$. In the granites, the 
plagioclase An content ranges from 12 to 18, and the potassium feldspar increases in abundance and size. The pegmatitic facies are characterized by large sodium feldspars, abundant potassium feldspars, and flakes of muscovite. This latter facies is commonly observed at the upper part of the east-Léré and north-Pala biotite-granite plutons, of the Zabili pluton, and of the Fianga intrusion. The distinctive feature of the leucogranite of Boularé is the occurrence of primary magmatic muscovite. In all the other granites, muscovite is either secondary and resulting from feldspar alteration, or it is late magmatic and replaces biotite. In the leucogranite, biotite is ferrous $\left(\mathrm{XMg}=0.39-0.42\right.$; $\left.\mathrm{TiO}_{2} \%=1.8-2.0\right)$, plagioclase is sodic (An 11-15), and potassium feldspar and quartz are abundant. No peculiar aluminous minerals (garnet, sillimanite or cordierite) were identified. The late intrusive pyroxene-bearing diorite close to Pala is characterized by residual crystals of orthoferrosilite (Mg\% 25.0-26.2, Fet.\% 70.1-72.1, Ca\% 2.7-2.9) mantled by Fe-augite (Mg\% 21.1-22.6, Fet.\% 36.4-44.9, Ca\% 32.4-42.5), poikilitic large flakes of Ti-biotite (XMg $\left.=0.25-0.27 ; \quad \mathrm{TiO}_{2} \%=4.1-4.4\right)$, abundant prisms of apatite, and sub-idiomorphic crystals of Ti-magnetite $\left(\mathrm{TiO}_{2} \%=5.6-6.0\right)$ and ilmenite, in a granular textured assemblage of Fe-augite, plagioclase An 22-26, potassium feldspar and quartz.

The biotites of the G3a tonalite belong to the calc-alkaline association of granitoids (Fig. 8). Biotites of the G3b granites and even of the leucogranite are also calc-alkaline. However, the granite biotites straddle the boundary between the calc-alkaline granitic and ferropotassic monzonitic associations. Biotites of the pyroxene-bearing diorite belong to the ferro-potassic monzonitic association. The barometer of Al-in-amphibole (Schmidt, 1992) calculated for the cores of the magmatic amphibole, gives 3.6-4.1 \pm 0.6 kbars.

\subsubsection{Geochemistry}

The analytical data are given in Table 2. The G3a tonalites and trondhjemites are characterized by silica contents of up to $68 \%$ for the trondhjemites, and high sodium contents $\left(0.3<\left(2 x \mathrm{~K}_{2} \mathrm{O}\right) / \mathrm{Na}_{2} \mathrm{O}<0.4\right)$. The incompatible element profiles are close to those of the $\mathrm{G} 2$ tonalites for the Mabadgé trondhjemite, or intermediate between those of the G2 tonalites and the G3b granites for the Lampto tonalite (Fig. 9B). This suggests a magmatic source close to that of the G2 tonalites, with a contribution from the source of the G3b granites.

The G3b monzogranites, biotite-granites, aplites and pegmatites are associated in comagmatic plutons. The silica contents range from $66 \%$ to $76 \%$, and the alkali contents from $6.2 \%$ to $9.2 \%$, with a high-K alkali ratio $\left(1.2<\left(2 x \mathrm{~K}_{2} \mathrm{O}\right) / \mathrm{Na}_{2} \mathrm{O}<2.7\right)$ for the granites. The alumina ratio is very fairly peraluminous $(1.0<\mathrm{A} /(\mathrm{CNK})<1.1)$. The trace element patterns of the granites exhibit random fractionation $\left(2.3<(\mathrm{La} / \mathrm{Yb})_{N}<22.4\right)$, reflecting a weak depletion or the lack of depletion of the HREE and HFSE (Fig. 9C). Thorium and rubidium are enriched $\left(1.6<(\mathrm{Th} / \mathrm{La})_{N}<2.3\right)$. The Nb-negative anomaly is variable $\left(0.1<(\mathrm{Nb} / \mathrm{La})_{N}<0.5\right)$. In most of the granites, $\mathrm{Ta}$ is enriched compared to $\mathrm{Nb}$ $\left(1.4<(\mathrm{Ta} / \mathrm{Nb})_{N}<1.6\right)$. High $\mathrm{Sr}-$ and Ti-negative anomalies and moderate Ba- and Eunegative anomalies can be explained by mineral fractionation processes. The random trace element depletions in aplite and pegmatite are due to pneumatolytic activity and escape. The overall chemical features are consistent with a lower to upper continental crust magmatic origin. In contrast to their very different mineralogical and major element compositions, G3b granites and G1 gabbros share similar trace element enrichment and weak $\mathrm{Nb}-\mathrm{Ta}$ anomalies (Fig. 9D). The trace element resemblances may be due to the contribution of similar continental crust material, in the subduction-related component of the mantle source, or in the crustal magmatic source. 
The leucogranite has a moderately peraluminous and potassic composition (A/CNK = 1.1; $\left.\left(2 x \mathrm{~K}_{2} \mathrm{O}\right) / \mathrm{Na}_{2} \mathrm{O}=1.2\right)$. It is poor in incompatible elements, but enriched in $\mathrm{Rb}, \mathrm{Ba}$, and $\mathrm{Sr}$. Except for these latter elements, the chemical fractionation is mild $\left((\mathrm{La} / \mathrm{Yb})_{N}=12.4\right)$, and the $\mathrm{Nb}$ - and Ta-negative anomaly is weak $\left((\mathrm{Nb} / \mathrm{La})_{N}=0.5\right)$. The potassium content is low and the Qtz-Ab-Or composition is far to the eutectic point ant does not corresponds to the minimum granitic temperature. The trace element composition is characteristic of a highly depleted evolved magma.

The two diorite samples of Pala (with or without pyroxene) share the same chemical features. They may belong to the same intrusion. The alkali ratio is potassic $\left(\left(2 x \mathrm{~K}_{2} \mathrm{O}\right) / \mathrm{Na}_{2} \mathrm{O}=1.7\right)$. The trace element content is high and moderately fractionated $\left(11.8<(\mathrm{La} / \mathrm{Yb})_{N}<13.4\right)$, with Th, $\mathrm{Ba}$ and $\mathrm{Rb}$ enrichments. The Nb-negative anomaly is very weak $\left(0.6<(\mathrm{Nb} / \mathrm{La})_{N}<0.7\right)$, and the Ta anomaly is insignificant. Sr- Eu- and Ti-negative anomalies can be explained by mineral fractionation of feldspar and oxides. These chemical features could be those of a fairly evolved crustal magma.

\section{Discussion}

\subsection{Structural data}

In the Mayo Kebbi Province, the structural data indicate the succession of the lithological units, in the following order: (1) the volcano-sedimentary Zalbi Group, (2) the gabbro-diorites G1, (3) the tonalite G2, and (4) the tonalites and granites G3. A major WNW-ESE compressional event took place after the deposition of the Group and its intrusion by the G1 gabbros. It may have occurred during or just after intrusion of the G2 foliated tonalite (Fig. 10). The basin formations and their marginal intrusive bodies exhibit the same structural features, characteristic of deformation at a supracrustal structural level. The Zalbi strata experienced isoclinal folding with fold axes trending $\mathrm{N} 30^{\circ}$, axial planes dipping $70^{\circ}$ to the west, and reverse faulting of the eastern contact. The gabbro bodies show mylonitization along reverse fault planes trending $\mathrm{N} 30^{\circ}$ and dipping $70^{\circ}$ to the west, with down dip stretching lineation. In contrast, the Gauthiot Fall tonalite experienced a ductile deformation at a low structural level, that developed a $\mathrm{N} 30^{\circ}$ striking and sub-vertical foliation, together with a horizontal stretching lineation. Such deformation is also compatible with a WNW-ESE compression, at a mesocrustal level (Fig. 10A). The later intrusion of a number of granitoid plutons occurred after significant shortening had ceased (Fig. 10B). These plutons invaded the supracrustal formations, creating xenoliths of amphibolites and gneisses and leaving many inter-pluton screens of the host country rocks. 

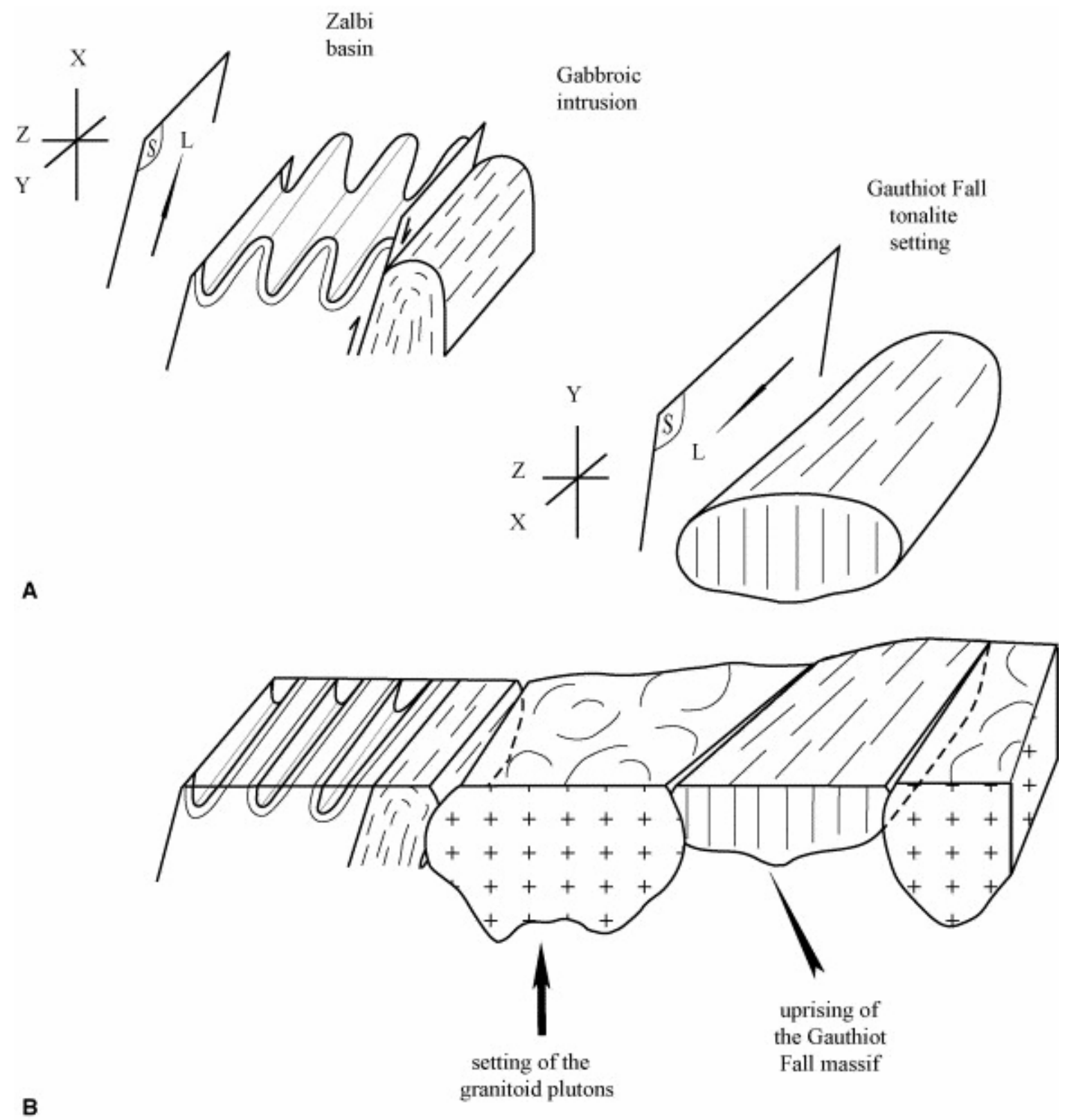

Fig. 10. Sketch of the tectonic setting of the successive group formations. A, pattern of the stress axes at high to low structural level, for the Zalbi Group and gabbro bodies, and for the Gauthiot Fall massif, respectively. The same compressional regime can be work in the two cases. B, uprising of the Gauthiot Fall massif and setting of post-tectonic granites.

\subsection{Petrochemical data}

The petrographic and geochemical data help to determine the geodynamic background. The Zalbi Group were deposited in a marine basin. The presence of slices of ultra-basic rocks, at the base of the basin supports the model of a thinned crustal basement under an extensional tectonic regime. The occurrence of acidic ash layers, the orogenic signature of the lava pyroxenes, and the fairly enriched calc-alkaline trace element patterns of these lavas indicate their location proximal to an active margin. However, the contemporaneous volcanic arc is not clearly identified. Eruption of the spilite flows of the upper Unit was due to renewal of the extensional regime. The G1 gabbroic intrusives may be related to the magmatic activity of the 
active margin. The orogenic chemical signature of the G2 tonalites is more consistent with a setting below a continental active margin, under high pressure of 6-7 kbars (amphibole barometer). This active margin must have existed before the WNW-ESE compressional event. The post-tectonic patterns of the G3 granitoid plutons agree with their post-orogenic magmatic signature (averaged low Nb-Ta depletion and moderate Rb enrichment). The first magmatic pulse of tonalitic composition, G3a, was emplaced in the middle crust under a pressure of 5-6 kbars (amphibole barometer). The granite plutons of the second pulse, G3b, reached higher crustal levels. The pyroxene-bearing diorites show a more evolved composition and were emplaced at around 4 kbars (amphibole barometer). They belong to the ferro-potassic association that is a common association in a post-orogenic context.

\subsection{Regional geodynamic interpretation}

The Zalbi Group is the equivalent of the Poli Group and of the Rei Bouba Group (Toteu et al., 1984, Toteu et al., 1987 and Pinna et al., 1994), which crop out around Poli and Tcholliré (Fig. 11). These Groups are composed of low-grade metavolcanic and metasedimentary rocks. Both mafic and acidic lavas are reported. In the Poli Group, a rhyolite has been dated by the $\mathrm{U} / \mathrm{Pb}$ method, yielding an upper intercept age of $830 \pm 12 \mathrm{Ma}$ (Toteu et al., 1987). The Rei Bouba Group is in the southern extension of the Goueygoudoum basin. In this Group, a $\mathrm{Pb} / \mathrm{Pb}$ date on zircons from a dacite, yields an age of $750 \pm 20$ Ma (Pinna et al., 1994). These volcano-sedimentary formations are associated with the calc-alkaline igneous rocks of the Poli Complex and of the Sinassi massif. These rocks consist of tonalites and trondhjemites, dated by $\mathrm{Rb} / \mathrm{Sr}$ isochron at $677 \pm 40 \mathrm{Ma}$ (Pinna et al., 1994). They are interpreted as the deep parts of a volcanic arc built between 750 and 670 Ma (Toteu et al., 1987 and Pinna et al., 1994). In that case, the Rei Bouba Group can be defined as a back-arc basin, in relationship with an oceanic plate subduction below the south-eastern continental margin of the Adamaoua-Yadé domain. If this model is true, the Zalbi basin and some parts of the Poli basin could be interpreted as remnants of a fore-arc basin.

Three up-to-date $\mathrm{Pb} / \mathrm{Pb}$ dates for the gabbro intrusions east of the Zalbi basin yield an average age of $730 \mathrm{Ma}$ (Penaye et al., this issue). Hence, these gabbros may have intruded the fore-arc basin before thrusting. The tonalite of the Gauthiot Fall massif yields a $\mathrm{Pb} / \mathrm{Pb}$ date ca. $665 \mathrm{Ma}$ (Penaye et al., this issue). Its chemistry is consistent with intrusion in an arc setting. In this model, the fore-arc basin, the volcanic arc, and the back-arc basin constitute the Léré-Poli terrane. This terrane represents an active margin system that was accreted onto the Adamaoua-Yade continental block along the Tchollire tectonic zone during the WNW-ESE compressional event. The Adamaoua-Yade block (Fig. 12) is constituted by Palaeoproterozoic terrains remobilized in the Neoproterozoic (Toteu et al., 2001 and Toteu et al., 2004). Later, post-tectonic granitoid plutons intruded the fractured volcanic arc area. Initially, the G3a plutons have an arc geochemical signature. In a later intrusive stage, an elevated geothermal gradient caused by arc magmatism initiated partial melting of the lower crust, and generated the G3b granites. Previous U/Pb dating of the syn-tectonic diorites and granites of northern Cameroon yield ages between 665 and 633 Ma (Toteu et al., 1987). Granite deformed by the transcurrent movement along the Tcholliré shear zone has been dated, by the $\mathrm{Pb} / \mathrm{Pb}$ zircon method, at $639 \pm 20 \mathrm{Ma}$ (Pinna et al., 1994). A more recent and precise $\mathrm{Pb} / \mathrm{Pb}$ date for a posttectonic G3a tonalite of the Léré area is $638.5 \pm 0.9 \mathrm{Ma}$ (Penaye et al., this volume). The posttectonic granite setting is therefore younger than $640 \mathrm{Ma}$, just after the compressional event and the accretion of the Léré-Poli Terrane (Penaye et al., this volume). 

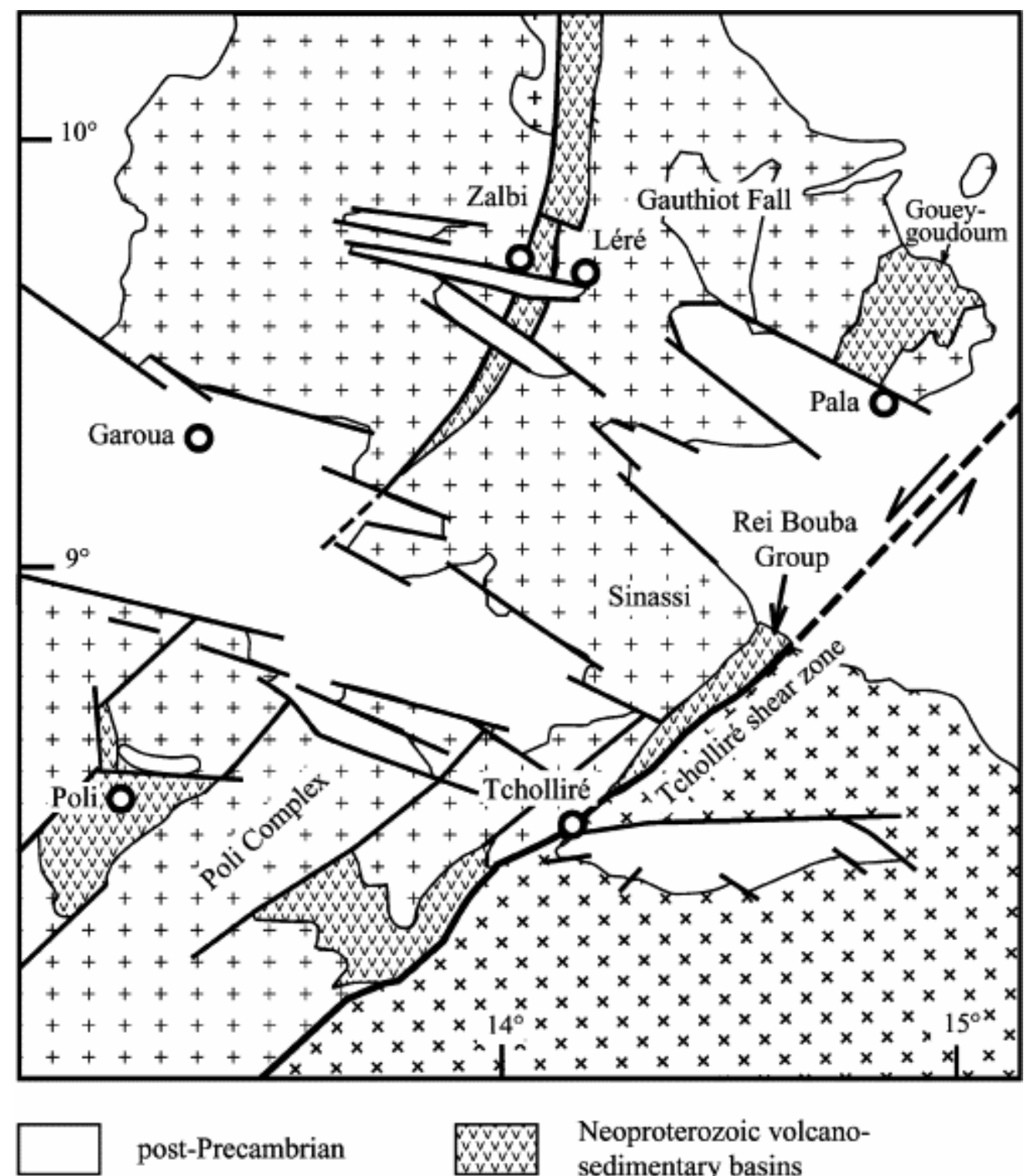

post-Precambrian

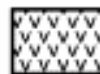

Neoproterozoic volcanosedimentary basins

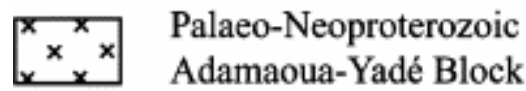

\section{undifferentiated pre- to post-tectonic \\ Neoproterozoic igneous rocks}

Fig. 11. Location of the volcano-sedimentary Neoproterozoic basins in the Léré and Poli region (south-Chad and north-Cameroon). The basins are limited, to the south-east, by the Tcholliré shear zone, at the edge of the Palaeo- and Neoproterozoic remobilized block of Adamaoua-Yadé, and to the north-west, by the badly defined Zalbi tectonic zone, at the border of the Neoproterozoic West-Cameroon of Garoua Block. Between the two basin trends, the Gauthiot Fall, Sinassi and Polii Complex tonalitic bodies share the same arc-related signature. The entire area is intruded by post-tectonic granites 


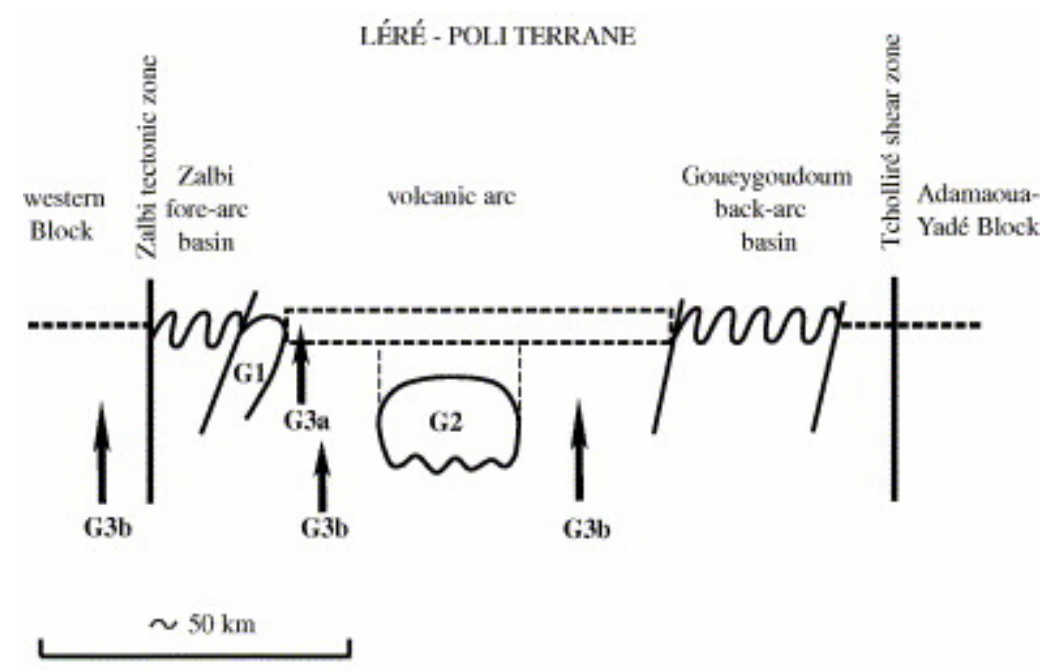

\footnotetext{
G1 : Fore-arc mafic intrusions

G2 : Volcanic arc tonalitic root

G3 : Late to Post-tectonic felsic plutons

a, late-tectonic tonalite-trondhjemite

b. post-tectonic granitoids
}

Fig. 12. Interpretation of the Léré-Poli region (Fig. 11 map) in term of a fore-arc basin—volcanic arc-back-arc basin terrane accreted to the Adamaoua-Yadé Block.

In the model presented here (Fig. 12), the Léré-Poli volcanic arc resulted from eastward subduction of an ocean domain located between the Adamaoua-Yadé Block and a western block. In this interpretation, the west Zalbi tectonic zone corresponds to the suture zone of the vanished ocean. The Tcholliré shear zone is the accreted zone of the arc system that constitutes the Léré-Poli Terrane. This area preserves geophysical evidence for crustal thinning from the Adamaoua-Yadé Block to the Léré-Poli Terrane (orbath et al., 1984).

In a paper by Tchameni et al. (this issue), we investigated the Pan-African igneous rocks that intruded the remobilized Adamaoua-Yadé Block containing Palaeoproterozoic relicts (Penaye et al., 1989 and Toteu et al., 2001). We interpreted these rocks to record building of a SW-NE volcanic arc, the Ngaoundéré arc, that belonged to a continental active margin resulting from ocean subduction (Fig. 13). Previous U/Pb dating of a metadiorite in this arc yields 620 $\pm 10 \mathrm{Ma}$ (Toteu et al., 2001). The subducted ocean may have been located either to the northwest of the Adamaoua-Yadé Block, with a south-eastward subduction, or to the south-east, with a north-westward subduction. The ocean suture is the Tcholliré shear zone, in the first case, and the Central Cameroon fault or the Sanaga fault, in the second case. The first interpretation is inconsistent with the Léré-Poli arc structure and with the fact that the last magmatic production of the Ngaoundéré arc post-dated the accretion of the Léré-Poli Terrane along the Tcholliré shear zone. The Central Cameroon fault is a good candidate for the suture zone of an oceanic subduction; however, the Sanaga fault cannot be discarded, if it is demonstrated that the Ngaoundéré arc extended south of the Central Cameroon fault. Consequently, the Adamaoua-Yadé Block does not belong to the Palaeoproterozoic northern part of the Congo Craton, but to a distinct northeastern craton, that may be the "Nile ghost Craton” (Toteu et al., 1990), partly preserved as Archean to Palaeoproterozoic remobilized remnants in the Saharan Metacraton (Abdelsalam et al., 2002). 


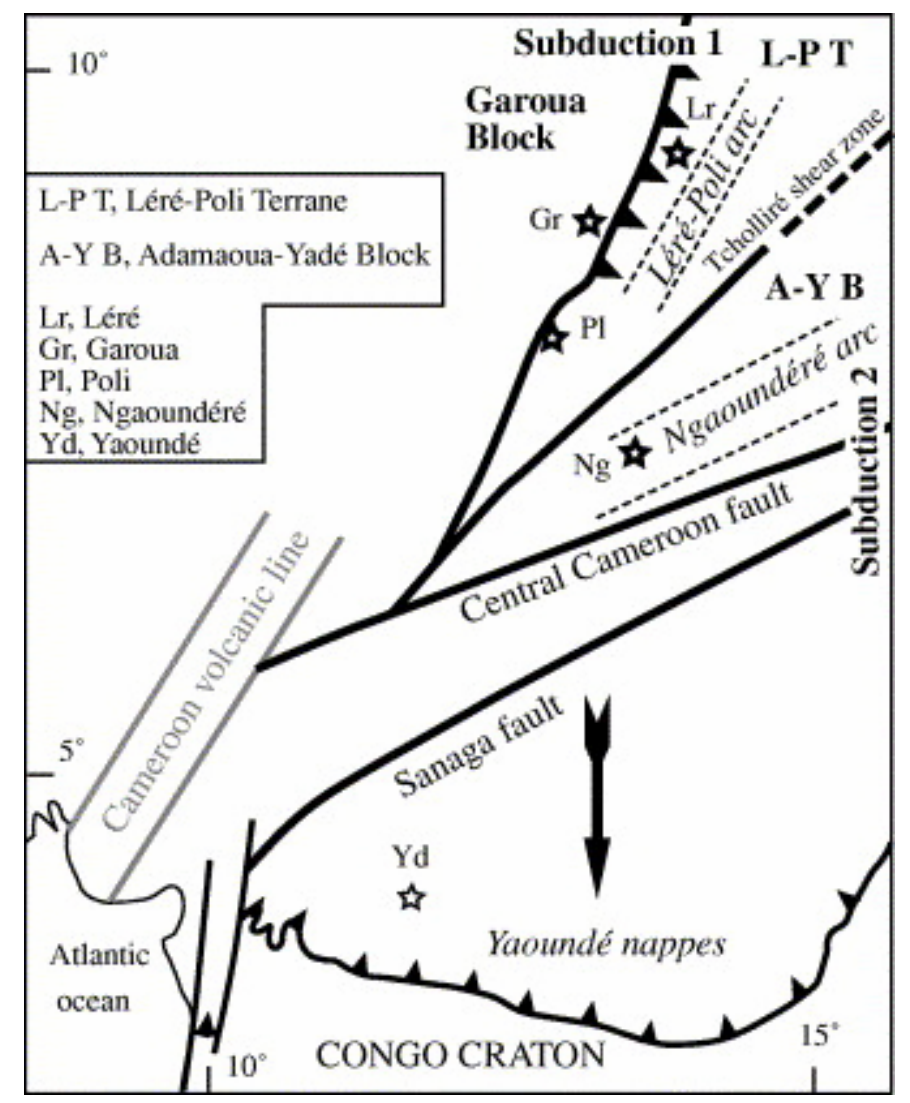

Fig. 13. Position of the Lété-Poli Terrane in the Pan-African Belt. Subduction is suspected, along the Zalbi tectonic zone, with east-south-eastward demising of an ocean, that was between the western Transaharian terranes belonging to the Touareg Craton, and the eastern Saharo-Nilotic Craton (Fig. 1).

\section{Conclusion}

In southern Chad and northern Cameroon, the Lake Léré region exposes the various Neoproterozoic terrains that preserve the geodynamic history of the northern part of the Central African fold belt (Fig. 1). Four structural groups are distinguished. In sequence, these are (1) the Volcano-Sedimentary Group of Zalbi (VSZ) located in the Zalbi and Goueygoudoum basins, (2) a first intrusion phase of gabbros-diorites (G1), (3) a second intrusion phase of tonalites (G2), and (4) a third and more extensive stage of batholithic dioritic to granitic plutons (G3); (Fig. 2, Fig. 3, Fig. 4, Fig. 5 and Fig. 6). In the Zalbi basin, the VSZ consists of four units: a basaltic pile with pyroxenite cumulate layers and ultra-basic slices, sand to clay sequence succession, a black shale deposit including acidic ash-fall layers, and an upper stack of spilitic flows. All these formations are isoclinally folded and cut by steeply dipping reverse faults at their eastern edge. The structural features point to a WNW to ESE compression. Lithology, petrography and geochemistry of the mafic rocks indicate an extensional geotectonic setting and the proximity of a volcanic arc. The trace element signature of the basalts is intermediate between those of back-arc basin basalts and of continental tholeiites (Fig. 7). The G1 bodies are protomylonitized quartz-gabbroic intrusions at the edges of the Zalbi basin. They underwent the same ESE-directed compression. Their petrochemical signature is calc-alkaline (Fig. 8 and Fig. 9), and may be related to an active margin setting. The G2 formation is a large foliated tonalitic massif. Its structural pattern can be explained by the WNW-ESE compressional stress, at a low structural level (Fig. 10). Subsequently, the massif was uplifted to a supracrustal position. The geochemical patterns are 
consistent with a Chili-type continental active margin setting. The G3 batholith is made of associated post-tectonic plutons. Two magmatic pulses are distinguished. The first pulse provided tonalitic magmas (ig. ) that could have been supplied by residual reservoirs of the volcanic arc. The second pulse corresponds to the abundant granitic plutons emplaced into supracrustal formations metamorphosed in the greenschist to amphibolite facies between the intrusive bodies. Petrographic compositions range from leucogranite, biotite-granite, monzogranite, granodiorite to diorite. All these rocks share the same calc-alkaline to monzonitic post-orogenic signature (Fig. 9).

In northern Cameroon, the pre-tectonic Poli and Rei Bouba volcano-sedimentary basins are the equivalent of the Zalbi and Goueygoudoum basins, respectively (Fig. 11). The associated igneous formations are tonalitic to trondhjemitic intrusive rocks showing a calc-alkaline arcrelated signature. Following the assumption of Pinna et al. (1994) of an arc and back-arc basin system linked to a subduction beneath the Adamoua-Yadé Block, we interpret the Léré region in term of fore-arc basin-volcanic arc-back-arc basin that were accreted to the AdamouaYadé Block, along the Tcholliré shear zone (Fig. 12). This model implies the subduction of a western ocean that was located between the West-Cameroon or Garoua Block that could have belonged to the Central Saharan Ghost Craton (Black and Liégeois, 1993) and the remobilized Palaeoproterozoic Adamoua-Yadé Block (ig. 13). All these terranes are now included in the southern part of the Saharan Metacraton (Abdelsalam et al., 2002), which therefore represents the amalgamation of juvenile arc-related formations and of different old blocks coming from two former cratons.

\section{Acknowledgements}

This work was partly supported by the "Projet CORUS" of the "Ministère des Affaires Etrangères de France”, and by the "Institut des Sciences de la Terre d'Orléans". Thanks are due to the reviewers, Drew Coleman and Mohamed Abdelsalam, for constructive criticism of the manuscript, and to John Bennett for improving the English.

\section{References}

Abdelsalam et al., 2002 M.G. Abdelsalam, J.-P. Liégeois and R.J. Stren, Review the saharan metacraton, Journal of African Earth Sciences 34 (2002), pp. 119-136.

Black and Liégeois, 1993 R. Black and J.-P. Liégeois, Cratons, mobile belts, alkaline rocks and continental lithospheric mantle: The Pan-African testimony, Journal of the Geological Society, London 150 (1993), pp. 89-98.

Dorbath et al., 1984 L. Dorbath, C. Dorbath, G. Stuart and D. Fairhead, Structure de la croûte sous le plateau de l'Adamoua (Cameroun), Comptes Rendus de l'Académie des Sciences, Paris 298 (1984), pp. 539-542.

Hickey et al., 1986 R.L. Hickey, F.A. Frey and D.C. Gerlach, Multiple sources for basaltic arc rocks from the southern volcanic zone of the Andes (34-41 $\left.{ }^{\circ} \mathrm{S}\right)$ : trace element and isotopic evidence for contributions from subducted oceanic crust, mantle and continental crust, Journal Geophysical Research 91 (1986), pp. 5963-5983. 
Holm, 1985 P.E. Holm, The geochemical fingerprints of different tectono-magmatic environments using hygromagmatophile element abundance of tholeiitic basalts and basaltic andesites, Chemical Geology 51 (1985), pp. 303-323.

Jahn et al., 1981 B.M. Jahn, A.Y. Glikson, J.-J. Peucat and A.H. Hickman, REE geochemistry and isotopic data of the Archean silicic volcanics and granitoids from the Pilbara Block, Western Australia: implications for the early crustal evolution, Geochimica and Cosmochimica Acta 45 (1981), pp. 1633-1652.

Kasser, 1995 Kasser, M.Y., 1995. Evolution précambrienne de la region du Mayo Kebbi (Tchad). Un segment de la chaîne panafricaine. Thèse, Muséum National d'Histoire Naturelle, Paris, 217p.

Kusnir, 1995 Kusnir, I., 1995. Géologie, ressources minérales et ressources en eau du bassin du lac Tchad. $2^{\text {ème }}$ édition, CNAR, N’Djaména, 115p.

Kusnir and Moutaye, 1997 I. Kusnir and H.A. Moutaye, Ressources minérales du Tchad: une revue, Journal of African Earth Sciences 24 (1997), pp. 549-562.

Leterrier et al., 1982 J. Leterrier, R.C. Maury, P. Thonon, D. Girard and M. Marchal, Clinopyroxene composition as a method of identification of the magmatic affinities of paleovolcanic series, Earth and Planetary Science Letters 59 (1982), pp. 139-154.

Martin, 1993 H. Martin, The mechanisms of petrogenesis of the Archean continental crustcomparison with modern processes, Lithos 30 (1993), pp. 373-388.

Penaye et al., 1989 J. Penaye, S.F. Toteu, A. Michard, J.-M. Bertrand and D. Dautel, Reliques granulitiques d'âge Proterozoi"que inférieur dans la zone mobile Panafricaine d'Afrique Centrale au Cameroun; Géochronologie U-Pb sur zircons, Comptes Rendus de l'Académie des Sciences, Paris 309 (1989), pp. 315-318.

Penaye et al., this issue Penaye, J., Kröner, A., Toteu, S.F., Van Schmus, W.R., Doumnang, J.-C., (this issue). Evolution of the Mayo Kebbi region as revealed by zircon dating: An early (ca. $740 \mathrm{Ma}$ ) Pan-African magmatic arc in southwestern Chad. Journal of African Earth Sciences.

Pinna et al., 1994 P. Pinna, J.-Y. Calvez, A. Abessolo, J.-M. Angel, T. Mekoulou-Mekoulou, G. Mananga and Y. Vernhet, Neoproterozoic events in the Tcholliré area: Pan-African crustal growth and geodynamics in central-northern Cameroon (Adamawa and North Provinces), Journal of African Earth Sciences 18 (1994), pp. 347-353.

Pouclet et al., 1995 A. Pouclet, J.-S. Lee, Ph. Vidal, B. Cousens and H. Bellon, Cretaceous to Cenozoic volcanism in South Korea and in the Sea of Japan: magmatic constraints on the opening of the back-arc basin. In: J.L. Smellie, Editor, Volcanism associated with extension at consuming plate margins, Journal Geological Society, London Special Publication 81 (1995), pp. 169-191.

Rossi and Chèvremont, 1987 Rossi, Ph., Chèvremont, P., 1987. Classification des associations magmatiques des granitoı"des: application à la cartographie des granitoı"des dans le cadre de la carte géologique à 1/50.000 de la France. Géochronique 21: pp. 14-18. 
Schmidt, 1992 M.W. Schmidt, Amphibole composition in tonalite as a function of pressure: an experimental calibration of the Al-in-hornblende barometer, Contribution Mineralogy Petrology 110 (1992), pp. 304-310.

Schneider and Wolff, 1992 Schneider, J.L., Wolff, J.P., 1992. Carte géologique et cartes hydrogéologiques à 1/500.000 de la République du Tchad. Mémoire explicatif. Document 209 du BRGM, Orléans, France.

Sun and McDonough, 1989 S.S. Sun and W.F. McDonough, Chemical and isotopic systematics of oceanic basalts: implications for mantle composition and processes. In: A.D. Saunders and M.J. Norry, Editors, Magmatism in the ocean basins, Geological Society of London Special Publication 42 (1989), pp. 313-345.

Tchameni et al., this issue Tchameni, R., Pouclet, A., Penaye, J., Ganwa, A.A., Toteu, S.F., (this issue). Petrography and geochemistry of the Ngaoundéré Pan-African granitoids in Central North Cameroon: Implications for their sources and geological setting. Journal of African Earth Sciences

Thorpe et al., 1984 R.S. Thorpe, P.W. Francis and L. O’Callaghan, Relative roles of source composition, fractional crystallization and crustal contamination in the petrogenesis of Andean volcanic rocks, Philosophical Transactions Royal Society London A 310 (1984), pp. 675-682.

Toteu et al., 1984 S.F. Toteu, J.-F. Dumont, J. Bassahak and J. Penaye, "Complexe de base” et "Séries intermédiaires" dans la zone mobile pan-africaine de la région de Poli, au Cameroun, Comptes Rendus de l'Académie des Sciences, Paris 299 (1984), pp. 561-564.

Toteu et al., 1987 S.F. Toteu, A. Michard, J.-M. Bertrand and G. Rocci, U/Pb dating of Precambrian rocks from northern Cameroon, orogenic evolution and chronology of the PanAfrican belt of Central Africa, Precambrian Research 37 (1987), pp. 71-97.

Toteu et al., 1990 Toteu, S.F., Bertrand, J.-B., Penaye, J., Macaudière, J., Angoua, S., Barbey, P., 1990. Cameroon: a tectonic keystone in the Pan-African network. In: Lewry, J.L., Stauffer, M.R. (Eds.), The Early Proterozoic Trans-Hudson Orogen of North America. Geological Association of Canada Special Paper, vol. 37, pp. 483-496.

Toteu et al., 2001 S.F. Toteu, R.W. Van Schmus, J. Penaye and A. Michard, New U-Pb and Sm-Nd data from north-central Cameroon and its bearing on the pre-Pan-African history of central Africa, Precambrian Research 108 (2001), pp. 45-73.

Toteu et al., 2004 S.F. Toteu, J. Penaye and Y.H. Poudjom Djomani, Geodynamic evolution of the Pan-African belt in Central Africa with special reference to Cameroon, Canadian Journal Earth Sciences 41 (2004), pp. 73-85. 